\title{
Impact of ocean carbon system variability on the detection of temporal increases in anthropogenic $\mathrm{CO}_{2}$
}

\author{
Naomi Marcil Levine, ${ }^{1}$ Scott C. Doney, ${ }^{2}$ Rik Wanninkhof, ${ }^{3}$ Keith Lindsay, ${ }^{4}$ \\ and Inez Y. Fung ${ }^{5}$ \\ Received 7 February 2007; revised 20 September 2007; accepted 28 November 2007; published 19 March 2008
}

[1] Estimates of temporal trends in oceanic anthropogenic carbon dioxide $\left(\mathrm{CO}_{2}\right)$ rely on the ability of empirical methods to remove the large natural variability of the ocean carbon system. A coupled carbon-climate model is used to evaluate these empirical methods. Both the $\Delta C^{*}$ and multiple linear regression (MLR) techniques reproduce the predicted increase in dissolved inorganic carbon for the majority of the ocean and have similar average percent errors for decadal differences $(24.1 \%$ and $25.5 \%$, respectively). However, this study identifies several regions where these methods may introduce errors. Of particular note are mode and deep water formation regions, where changes in air-sea disequilibrium and structure in the MLR residuals introduce errors. These results have significant implications for decadal repeat hydrography programs, indicating the need for subannual sampling in certain regions of the oceans in order to better constrain the natural variability in the system and to robustly estimate the intrusion of anthropogenic $\mathrm{CO}_{2}$.

Citation: Levine, N. M., S. C. Doney, R. Wanninkhof, K. Lindsay, and I. Y. Fung (2008), Impact of ocean carbon system variability on the detection of temporal increases in anthropogenic $\mathrm{CO}_{2}, J$. Geophys. Res., 113, C03019, doi:10.1029/2007JC004153.

\section{Introduction}

[2] Since the start of the industrial revolution, anthropogenic activity, such as fossil fuel combustion, has resulted in the emission of large quantities of carbon dioxide $\left(\mathrm{CO}_{2}\right)$ into the atmosphere. The resulting increase of atmospheric $\mathrm{CO}_{2}$ over the past several centuries has been well documented from high-resolution ice cores [e.g., Etheridge et al., 1996] and, starting in 1957, direct measurements [e.g., Keeling et al., 1976; Keeling and Whorf, 1994]. As $\mathrm{CO}_{2}$ is a potent greenhouse gas, increased atmospheric concentrations are projected to increase surface temperatures, resulting in shifts in regional and global climates [e.g., Hansen et al., 2006; Intergovernmental Panel on Climate Change (IPCC), 2001]. Consequently, there is great interest in quantifying the current and future rates of increase of atmospheric $\mathrm{CO}_{2}$ and predicting the effect of these increased concentrations on the global climate [e.g., Dilling et al., 2003].

\footnotetext{
${ }^{1}$ Massachusetts Institute of Technology/Woods Hole Oceanographic Institution Joint Program, Woods Hole, Massachusetts, USA.

${ }^{2}$ Marine Chemistry and Geochemistry Department, Woods Hole Oceanographic Institution, Woods Hole, Massachusetts, USA.

${ }^{3}$ Atlantic Oceanographic and Meteorological Laboratory, NOAA, Miami, Florida, USA.

${ }^{4}$ Climate and Global Dynamics, National Center for Atmospheric Research, Boulder, Colorado, USA.

${ }^{5}$ Berkeley Atmospheric Sciences Center, University of California, Berkeley, California, USA.
}

Copyright 2008 by the American Geophysical Union. 0148-0227/08/2007JC004153\$09.00
[3] Not all anthropogenic $\mathrm{CO}_{2}$ remains in the atmosphere. Current estimates are that the oceans and terrestrial biosphere have each removed $\sim 30 \%$ of anthropogenic $\mathrm{CO}_{2}$ emissions over the past 20 years [IPCC, 2001; Sabine et al., 2004a]. Because of large uncertainties on these estimates, there are ongoing efforts to better quantify the magnitude of these two sinks using a combination of field programs, empirical methods, and numerical models. For the oceans a major focus is on directly measuring the temporal change in the oceanic dissolved inorganic carbon (DIC) inventory through time series and repeat hydrographic sections [Peng et al., 1998; Wallace, 1995, 2001]. The U.S. and international Climate Variability and Predictability (CLIVAR) $/ \mathrm{CO}_{2}$ programs (U.S. and international CLIVAR/ $/ \mathrm{CO}_{2}$ data are available at http://ushydro.ucsd.edu and http://ioc.unesco.org/ ioccp, respectively), for example, are monitoring the oceans' response to anthropogenic $\mathrm{CO}_{2}$ and climate change through reoccupation on approximately a decadal timescale of key sections from the 1990s World Ocean Circulation Experiment (WOCE)/Joint Global Ocean Flux Study global $\mathrm{CO}_{2}$ survey.

[4] The ocean carbon system exhibits significant natural climate variability on subannual to decadal and longer timescales. This natural variability complicates efforts to constrain oceanic anthropogenic $\mathrm{CO}_{2}$ uptake via direct measurements of DIC temporal changes. For example, an estimate of the increase in DIC due to anthropogenic $\mathrm{CO}_{2}$, $\Delta C_{\text {anthro}}$, can be computed by differencing observed DIC concentrations at two sampling times,

$$
\Delta C_{\text {anthro }}=C_{\text {obs }}\left(t_{1}\right)-C_{\text {obs }}\left(t_{0}\right) .
$$


However, this estimate will alias vertical and lateral heave of isopycnal surfaces associated with mesoscale eddies and frontal oscillations [Haine and Gray, 2001; Peacock et al., 2005] as well as shifts in water masses and water mass properties associated with interannual climate modes such as the El Niño-Southern Oscillation [Feely et al., 1999; Le Quere et al., 2003]. This is particularly a problem for field programs such as CLIVAR/ $/ \mathrm{CO}_{2}$, which sample on limited spatial and temporal timescales and so greatly undersample the natural variability of the ocean carbon system. However, these programs are currently one of the only ways of acquiring basin-scale, full depth ocean coverage.

[5] Two broad categories of methods have been proposed to correct observed DIC fields for natural variability in biology and circulation in order to detect secular trends in anthropogenic $\mathrm{CO}_{2}$ storage. The first approach estimates total anthropogenic $\mathrm{CO}_{2}\left(C_{\text {anthro }}\right)$, defined as the DIC concentration difference between current and preindustrial conditions. Empirical methods for estimating $C_{\text {anthro, first }}$ introduced by Brewer [1978] and Chen and Millero [1979], take the general form

$$
C_{\text {anthro }}=C_{\text {obs }}-C_{\text {eq }}-C_{\text {bio }}-C_{\text {diss }} \text {, }
$$

where $C_{\mathrm{obs}}$ is the observed DIC, $C_{\mathrm{eq}}$ is the equilibrium DIC concentration for a preindustrial atmosphere $(280 \mathrm{ppm})$, $C_{\mathrm{bio}}$ is the change in DIC due to remineralization of organic matter, and $C_{\mathrm{diss}}$ is the change in DIC due to the dissolution of calcium carbonate. Gruber et al. [1996] modified equation (2) by adding a term, $C_{\text {diseq, }}$ to account for the $\mathrm{CO}_{2}$ air-sea disequilibrium experienced by a water parcel when it was last at the surface,

$$
C_{\text {anthro }}^{C^{*}}=\Delta C^{*}-C_{\text {diseq }},
$$

where $\Delta C^{*}$ equals $C_{\text {anthro }}$ in equation (2). This technique (termed the $\Delta C^{*}$ method) corrects DIC for changes in rates of remineralization and dissolution using other tracers for these processes, such as apparent oxygen utilization (AOU) and the change in alkalinity. This requires the assumption that changes in $\mathrm{AOU}$ and alkalinity can be converted to changes in DIC using fixed ratios. In addition, the $\Delta C^{*}$ method does not account for changes in DIC resulting from isopycnal heave and so is typically applied along isopycnal surfaces to avoid biases in the estimate of $C_{\text {anthro }}$ [Gruber et al., 1996].

[6] The $\Delta C^{*}$ method is commonly used for estimating $C_{\text {anthro, }}$ albeit with subtle difference in application [Coatanoan et al., 2001; Gruber, 1998; Lee et al., 2003; Lo Monaco et al., 2005; Sabine and Feely, 2001; Sabine et al., 2002, 2004b, 1999; Wanninkhof et al., 1999]. Several other empirical methods have been proposed for estimating total anthropogenic $\mathrm{CO}_{2}$, including the tracer combining oxygen, inorganic carbon, and total alkalinity approach [Touratier and Goyet, 2004a, 2004b; Touratier et al., 2005] and the optimum multiparameter mixing analysis approach [Goyet et al., 1999]. Estimates of total anthropogenic $\mathrm{CO}_{2}$ can also be used to estimate the temporal change of $C_{\text {anthro }}, \Delta C_{\text {anthro, }}$ by differencing $C_{\text {anthro }}$ from two sampling times, for example [Peng et al., 1998; Sabine et al., 2004b],

$$
\Delta C_{\text {anthro }}^{C^{*}}=C_{\text {anthro }}^{C^{*}}\left(t_{1}\right)-C_{\text {anthro }}^{C^{*}}\left(t_{0}\right) .
$$

[7] The second approach for correcting observed DIC fields in order to estimate the temporal change in anthropogenic carbon, $\Delta C_{\text {anthro, }}$ utilizes multiple linear regression (MLR) analysis [Friis et al., 2005; Goyet and Davis, 1997; Peng, 2005; Peng et al., 2003; Sabine et al., 2004b, 1999; Wanninkhof et al., 2006a]. This technique, introduced by Brewer et al. [1995] and Wallace [1995], is a purely statistical method for removing variability in DIC due to natural changes in circulation and biological respiration and remineralization. The MLR method fits observed DIC as a function of physical (temperature and salinity) and biogeochemical (oxygen, phosphate, nitrate, and silicate) properties. $\Delta C_{\text {anthro }}$ is then estimated as the residual between the observed DIC and an MLR-calculated DIC, which is representative of some earlier time (see details in section 3.2),

$$
\Delta C_{\mathrm{anthro}}^{\mathrm{MLR}}=C_{\mathrm{obs}}\left(t_{1}\right)-C^{\mathrm{MLR}}\left(t_{0}\right)
$$

The basic assumption is that temporal variability in DIC due to natural processes will follow the linear spatial relationships derived using the MLR, while DIC changes due to anthropogenic activity will not. In theory the MLR should remove the majority of the DIC variability caused by heaving of isopycnal surfaces or shifts in fronts between water masses.

[8] As an alternative to the above mentioned empirical techniques, tracer-based proxy methods are often used to estimate the temporal evolution of anthropogenic $\mathrm{CO}_{2}$ in the ocean. These approaches use tracers, such as $\delta^{13} \mathrm{C}$ and chlorofluorocarbons, as proxies for anthropogenic $\mathrm{CO}_{2}$ [e.g., McNeil et al., 2003; Quay et al., 2003; Wallace, 1995; Waugh et al., 2006]. Often different empirical techniques and tracer approaches give significantly different inventory estimates and spatial distributions of anthropogenic carbon. Several studies have compared $C_{\text {anthro }}$ estimates made by these various techniques [Lo Monaco et al., 2005; Peng, 2005; Peng et al., 2003; Sabine et al., 1999; Wanninkhof et al., 1999]. However, determining the success or failure of these methods is difficult as the "true" anthropogenic signal is unknown. Several studies [e.g., Matsumoto and Gruber, 2005; Waugh et al., 2006] have addressed this problem by using the output of a global climate model as a synthetic data set to compare empirically based estimates of $C_{\text {anthro }}$ to the "true" anthropogenic signal in the model. Matsumoto and Gruber [2005] use this approach to conclude that the largest error in the $\Delta C^{*}$ estimate of $C_{\text {anthro }}$ is due to the uncertainty in the air-sea disequilibrium term.

[9] The objective of this study is to evaluate our ability to accurately estimate the increase of oceanic anthropogenic $\mathrm{CO}_{2}$ over time, $\Delta C_{\text {anthro }}$. To do this, we use the output of a coupled carbon-climate model as an artificial data set to which we apply commonly used empirical methods for estimating $\Delta C_{\text {anthro; }}$ our approach is similar to that of Matsumoto and Gruber [2005] but with an emphasis on temporal changes. To replicate the sampling schemes of repeat hydrography programs, which are reoccupying ocean sections on a $\sim 10$ year timescale, we sample model output for 2 months 10 years apart. We use this synthetic data set to determine where these methods may succeed and may fail 
in the context of ocean carbon variability and the current CLIVAR/CO2 Repeat Hydrography Program.

[10] This study compares the two most widely used techniques: $\Delta C^{*}$ and MLR. We find that both methods have similar average percent errors and RMS errors and do a reasonable job reproducing the temporal trends of the predicted anthropogenic signal. However, the $\Delta C^{*}$ method is unable to remove some of the natural variability in the ocean carbon cycle, particularly in high-latitude, deep convection regions, resulting in estimates of $\Delta C_{\text {anthro }}$ which deviate from the predicted values by up to $\pm 10 \mu \mathrm{mol} \mathrm{kg}{ }^{-1}$ per decade. This signal is comparable to or larger than the predicted secular trends over the 10 year sampling period. The MLR technique also has shortcomings primarily in its interpretation. Both methods have known problems in the upper $200 \mathrm{~m}$ and so cannot be applied robustly to this region.

\section{Coupled Carbon-Climate Model}

[11] The Climate System Model 1.4 (CSM1.4) carbon model [Doney et al., 2006] output is used as a synthetic data set to address the question of anthropogenic $\mathrm{CO}_{2}$ detection and attribution. The model has fully coupled physical climate and carbon cycle modules for the ocean, atmosphere, and land. The CSM1.4 model was developed in the framework of the National Center for Atmospheric Research (NCAR) Community Climate System model (CCSM) [Blackmon et al., 2001]. The physical model is composed of the NCAR Ocean Model, the NCAR Land Surface Model, the Community Climate Model (CCM), and the Community Sea Ice Model, which are coupled together so that mass and energy exchanges among the different reservoirs are conserved. The ocean model [Gent et al., 1998] is non-eddy resolving with a grid spacing of $3.6^{\circ}$ longitude and $0.8^{\circ}$ to $1.8^{\circ}$ latitude with 25 vertical levels. The land and atmospheric model resolution is $\sim 3.75^{\circ}$ with 18 vertical levels (for the atmosphere). The carbon module for each component is spun up individually in order to minimize drifts in the global carbon inventories. The land biogeochemical model is a modified version of the Carnegie-Ames-Stanford-Approach model. The ocean biogeochemical model is derived from the second Ocean Carbon-Cycle Model Intercomparison Project (OCMIP II) biotic model described by Najjar et al. [2007] and Najjar and Orr [1999]. Prognostic variables include DIC, dissolved organic matter (DOM), particulate organic matter (POM), phosphate $\left(\mathrm{PO}_{4}\right)$, dissolved organic phosphorus, oxygen $\left(\mathrm{O}_{2}\right)$, total dissolved inorganic iron, and alkalinity. Three significant modifications were made to the OCMIP II model: production (DOM, POM) is prognostically computed as a function of light, temperature, phosphate, and iron; iron is added as a limiting nutrient of biological production; and an iron cycle is incorporated into the model. Though ecosystem dynamics are not explicitly calculated in the model, model equations are fully prognostic. Therefore there is no nudging or restoring of variables during the model runs. A full description of the coupled climate model, including model biogeochemical equations, can be found in the work of Doney et al. [2006].

[12] A 1000 year control simulation of the CSM1.4 model compares reasonably well against observations, displaying stable surface temperatures $( \pm 0.10 \mathrm{~K})$ and atmospheric $\mathrm{CO}_{2}$ concentrations $( \pm 1.2 \mathrm{ppm})$ and relatively little deep ocean drift [Doney et al., 2006; Fung et al., 2005]. The largest discrepancies between the model and observations are in the equatorial Pacific Ocean in which CCM atmospheric dynamics create a dual intertropical convergence zone resulting in unrealistic precipitation patterns. Also, in the equatorial Pacific, simulated ocean biogeochemistry results in unrealistically low export production because of excessive iron limitation and problems with upwelling parameterizations [Doney et al., 2006].

[13] We focus on two model simulations: a 1000 year control run and the final 100 years from a transient run (1820-2100) forced with historic fossil fuel $\mathrm{CO}_{2}$ emissions up to 2000 and then the IPCC "business as usual" emissions scenario (A2) [IPCC, 2001, 2000]. The transient run (1820-2100) was started on year 101 of the control run. Because the simulations use prescribed $\mathrm{CO}_{2}$ emissions rather than prescribed atmospheric $\mathrm{CO}_{2}$ trajectory, the model years do not exactly match actual calendar years. The simulated atmospheric $\mathrm{CO}_{2}$ concentration in year 2000 therefore is somewhat low compared to observations ( 346.5 ppmv compared with $\sim 367$ ppmv), lagging about 12 years behind reality. While the model $\mathrm{CO}_{2}$ concentrations cannot be directly matched to calendar years, the overall $\mathrm{CO}_{2}$ temporal trends for the 21 st century and the year $2100 \mathrm{CO}_{2}$ concentration ( $\sim 765 \mathrm{ppmv})$ are comparable to those from other carbon-climate projections [Friedlingstein et al., 2006; Fung et al., 2005].

[14] Anthropogenic $\mathrm{CO}_{2}$ is not explicitly tracked in the CSM1.4 model; therefore the intrusion of anthropogenic $\mathrm{CO}_{2}$ into the ocean must be calculated from the model output. There are two approaches for this calculation. The first method computes $C_{\text {anthro }}$ by differencing the transient simulation and the corresponding time in the control run. However, because the physics of the fully coupled simulations evolve independently, the high-frequency variability is not coherent between the control and transient simulations. Therefore, for the CSM1.4 model, this is not an ideal method. We follow the second approach, which takes advantage of the temporal-scale separation between natural variability and anthropogenic secular trend by applying a low-pass filter to the high temporal resolution (monthly) output of the model. This removes the natural short-term variability in the ocean carbon cycle, revealing the underlying "anthropogenic" increase. This smoothed estimate of $C_{\text {anthro }}$ is imperfect as it misses short-term variations in the anthropogenic inventory caused by isopycnal heave.

[15] The magnitude of the short-term variability in $C_{\text {anthro }}$ is investigated using a pair of historical (1958-2004) ocean-only simulations [Lovenduski et al., 2007; Moore et al., 2004]. We compare the true $C_{\text {anthro }}$ estimate, calculated by differencing a control run and a transient run with identical surface forcing and nearly identical physical circulation, to a low-pass filter estimate of $C_{\text {anthro, }}$, calculated using a spline fit to the transient run. The true $C_{\text {anthro }}$ estimate and the low-pass filter estimate of $C_{\text {anthro }}$ for three representative latitudes are shown in auxiliary material ${ }^{1}$ Figure S1. This analysis indicates that the mean error

${ }^{1}$ Auxiliary materials are available in the HTML. doi:10.1029/ 2007JC004153. 

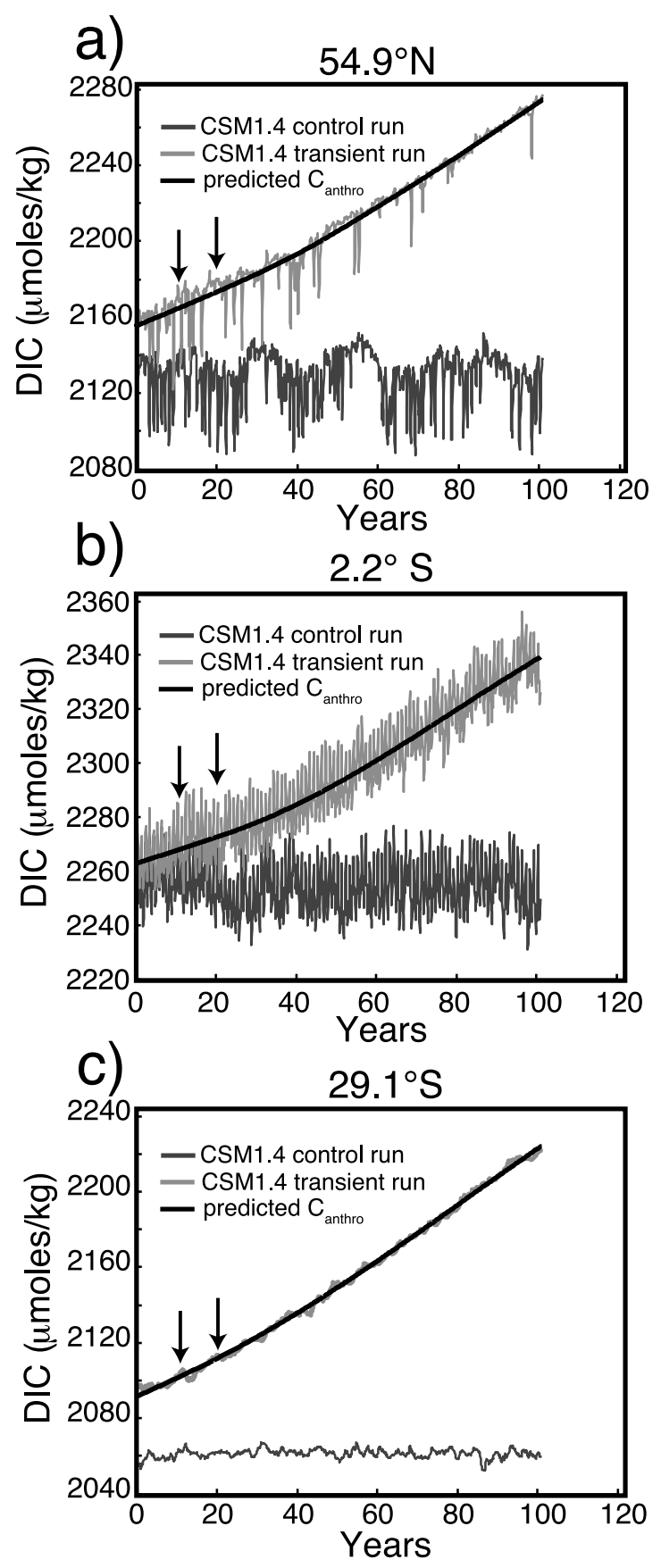

Figure 1. Time series of CSM1.4 model output along the A16 transect at $245 \mathrm{~m}$ and (a) $54.9^{\circ} \mathrm{N}$, (b) $2.2^{\circ} \mathrm{S}$, and (c) $29.1^{\circ} \mathrm{S}$. The model output, with the drift removed, for control run years 280-380 is shown in dark gray, the model output for the A2 transient run is shown in light gray, and the low-pass filter estimate of $C_{\text {anthro }}$ is shown in black. Arrows indicate the times at which the model was sampled for the decadal analyses.

introduced by the low-pass filter approximation of $C_{\text {anthro }}$ is $0.37 \mu \mathrm{mol} \mathrm{kg} \mathrm{kg}^{-1}$ per decade for the depth range $200-$ $2000 \mathrm{~m}$. The mode RMS deviation of the low-pass filter estimate from the true value for the ocean-only simulations is $0.13 \mu \mathrm{mol} \mathrm{kg}^{-1}$ per decade $(200-2000 \mathrm{~m})$. These errors are considerably smaller than either the natural variability or the errors in the $\Delta C^{*}$ and MLR techniques, emphasized in sections 4 and 5 . While the ocean-only simulations allow us to more accurately quantify $C_{\text {anthro, }}$, the coupled carbon model allows for the exploration of future carbon scenarios which include changing ocean dynamics. For this study a spline fit to CSM1.4 model output is used to calculate the low-pass filter estimate of $C_{\text {anthro }}, \Delta C_{\text {anthro }}^{\text {predicted }}$. Figure 1 shows CSM1.4 model DIC output for the A2 transient run and the corresponding 100 years of the control run for three representative model cells. Plotted in black are the spline fits used to estimate $\Delta C_{\text {anthro }}^{\text {predicted }}$.

[16] In the surface ocean (upper $50 \mathrm{~m}$ ) the A2 transient run exhibits an average DIC increase of $1.36 \mu \mathrm{mol} \mathrm{kg}^{-1} \mathrm{a}^{-1}$ for the model period corresponding to the decade with an average atmospheric $\mathrm{CO}_{2}$ of $375 \mathrm{ppm}$ (approximately calendar years 2000-2010). This is in agreement with present-day observed surface ocean DIC increases [Peng et al., 1998; Sabine et al., 2004b]. The accumulation of anthropogenic $\mathrm{CO}_{2}$ decreases rapidly with depth to an average value of $0.13 \mu \mathrm{mol} \mathrm{kg} \mathrm{kg}^{-1}(2500-5000 \mathrm{~m})$ during this period. The spatial distribution of anthropogenic $\mathrm{CO}_{2}$ in the model is also consistent with Sabine et al. [2004b], who estimate that 23\% of anthropogenic ocean carbon is stored in the North Atlantic (in the model, 26\% is in the North Atlantic), $9 \%$ is stored in the Southern Ocean (in the model, $9 \%$ is in the Southern Ocean), and $50 \%$ is found in the upper $400 \mathrm{~m}$ (in the model, 54\% is above $400 \mathrm{~m})$.

[17] We focus much of our analysis on a representative hydrographic section in the Atlantic Ocean. Monthly model output is extracted along a north-south transect at approximately $25^{\circ} \mathrm{W}$, corresponding to the WOCE Atlantic hydrographic section 16 (A16) cruise track [Johnson et al., 2005; Johnson and Gruber, 2007; Peltola et al., 2005; Wanninkhof et al., 2006b; U.S. CLIVAR/ $\mathrm{CO}_{2}$ data are available at ushydro.ucsd.edu]. This track was chosen because it bisects the Atlantic Ocean and includes both the North Atlantic Deep Water and Antarctic Intermediate Water formation regions, two important portals for $\mathrm{CO}_{2}$ injection into the deep ocean. To mimic the sampling strategy of the repeat hydrography programs, the A16 transect analysis is conducted using A2 transient run model output for 2 months exactly 10 years apart (mean atmospheric $\mathrm{CO}_{2}=375 \mathrm{ppm}$ ). The arrows in Figure 1 indicate the months used for the A16 transect analysis. Similar to field data, this sampling scheme aliases model DIC variability on timescales from monthly to decadal. A global analysis is also conducted (section 7) using annual mean model output extracted for 2 years exactly 10 years apart; this aliases DIC variability on timescales from interannual to decadal.

\section{Calculations}

\section{1. $\Delta C^{*}$ and $\Delta C_{\text {anthro }}^{C^{*}}$}

[18] The $\Delta C^{*}$ analysis was conducted using Gruber et al.'s [1996] formulation of equation (2)

$$
\begin{aligned}
\Delta C^{*}= & \mathrm{C}-\left.C_{\mathrm{eq}}\left(\mathrm{S}, \theta, \mathrm{Alk}^{0}\right)\right|_{f \mathrm{CO} 2} \\
= & 280 \mathrm{ppm}+r_{\mathrm{C}: \mathrm{O} 2}\left(\mathrm{O}_{2}^{\mathrm{sat}}-\mathrm{O}_{2}\right) \\
& +1 / 2\left[\left(\mathrm{Alk}^{0}-\mathrm{Alk}\right)+r_{\mathrm{N}: \mathrm{O} 2}\left(\mathrm{O}_{2}^{\mathrm{sat}}-\mathrm{O}_{2}\right)\right]
\end{aligned}
$$


where $r_{\mathrm{C}: \mathrm{O} 2}$ and $r_{\mathrm{N}: \mathrm{O} 2}$ are the Redfield stoichiometric ratios for $C_{\text {org }}: \mathrm{O}_{2}$ and $\mathrm{N}: \mathrm{O}_{2}$, respectively. In order to be consistent with the ocean biogeochemical model, Anderson and Sarmiento's [1994] modified Redfield ratios are used, $\mathrm{P}: \mathrm{N}: \mathrm{C}_{\mathrm{org}}: \mathrm{O}_{2}=1: 16: 117:-170 . \mathrm{O}_{2}^{\text {sat }}$ is the oxygen saturation concentration and is calculated using the equations of Weiss [1970]. $C_{\text {eq }}$ is the equilibrium DIC concentration given a preindustrial atmosphere (atmospheric $f \mathrm{CO}_{2}=280 \mathrm{ppm}$ ) and is calculated as a function of potential temperature $(\theta)$, salinity (S), preformed alkalinity $\left(\mathrm{Alk}^{0}\right)$, and $p \mathrm{CO}_{2}$ (280 ppm) using the $\mathrm{CO}_{2}$ System in Seawater code written by Zeebe and Wolf-Gladrow [2001] (http://www.soest. hawaii.edu/oceanography/faculty/zeebe_files/CO2_System in_Seawater/csys.html). $\mathrm{Alk}^{0}$ is the preformed alkalinity and is calculated using a multiple linear regression fit to upper ocean salinity $(\mathrm{S})$, phosphorus $(\mathrm{P})$, and oxygen $\left(\mathrm{O}_{2}\right)$ for years 101-450 of the control run. Model concentrations are converted from volume-normalized units to conventional mass-normalized units using a constant conversion factor $\left(1026 \mathrm{~kg} \mathrm{~m}^{-3}\right)$. Results are presented in $\mu \mathrm{mol} \mathrm{kg}$ for depth profiles and mol $\mathrm{m}^{-2}$ for column inventories.

[19] The preindustrial air-sea disequilibrium term $C_{\text {diseq }}$ (equation (3)) is assumed to remain constant with time along an isopycnal surface such that $C_{\text {diseq }}\left(t_{1}\right)=C_{\text {diseq }}\left(t_{0}\right)$ [Gruber et al., 1996]. Therefore from equations (3) and (4),

$$
\begin{aligned}
\Delta C_{\text {anthro }}^{C^{*}} & =\left(\Delta C^{*}\left(t_{1}\right)-C_{\text {diseq }}\left(t_{1}\right)\right)-\left(\Delta C^{*}\left(t_{0}\right)-C_{\text {diseq }}\left(t_{0}\right)\right) \\
& =\Delta C^{*}\left(t_{1}\right)-\Delta C^{*}\left(t_{0}\right) .
\end{aligned}
$$

$\Delta C^{*}$ and $\Delta C_{\text {anthro }}^{C^{*}}$ are calculated along isopycnal surfaces using monthly mean model output roughly following the A16 transect and then projected back into depth space. The error introduced by this remapping is approximately $1.0 \mu \mathrm{mol} \mathrm{kg} \mathrm{kg}^{-1}$. For the global calculations, $\Delta C^{*}$ and $\Delta C_{\text {anthro }}^{C^{*}}$ are calculated in depth space using annual mean model output because of computational constraints. We compare $\Delta C^{*}$ and $\Delta C_{\text {anthro }}^{C^{*}}$ calculated in depth and isopycnal space and conclude that while small differences exist, both the magnitude of the $\Delta C_{\text {anthro }}^{C^{*}}$ estimate and the major trends are the same for both calculations.

\subsection{Multiple Linear Regression and $\Delta C_{\text {anthro }}^{\mathrm{MLR}}$}

[20] There is no standard set of physical and biogeochemical variables for DIC MLR. Therefore the optimized MLR parameters differ depending upon the chosen variables and ocean region [Brewer et al., 1995; Friis et al., 2005]. As neither nitrate nor silicate is explicitly included in the model, we use oxygen and phosphate as the biogeochemical variables to compute the estimated DIC concentration, $C^{\text {MLR }}$

$$
C^{\mathrm{MLR}}=a+b \theta+c \mathrm{~S}+d \mathrm{O}_{2}+e \mathrm{PO}_{4},
$$

where $a-e$ are the optimized MLR parameters $(p)$. Model concentrations are converted from volume-normalized units to conventional mass-normalized units $\left(\mu \mathrm{mol} \mathrm{kg}{ }^{-1}\right)$ using a constant conversion factor $\left(1026 \mathrm{~kg} \mathrm{~m}^{-3}\right)$. Because of seasonal variability in the upper water column and differences between the hydrographic properties of thermocline and deep water masses, the MLR fits are done using temperature, salinity, and nutrient output from 200 to 2000 m [Brewer et al., 1995; Sabine et al., 1999; Wallace, 1995]. Though these fits are then applied to the entire water column, our analysis focuses on the results from 200 to $2000 \mathrm{~m}$ (see discussion in section 3.3). We perform a stepwise MLR (after Brewer et al. [1995]) to determine the number of variables needed to fit model DIC concentrations. The "best fit" is determined by comparing the $r^{2}$ value and the root-mean-square error of MLR fits using 1-4 variables. For CSM1.4 model output, including all four variables $\left(r^{2}=0.99\right.$; standard deviation of residual for $t_{0} \pm$ $\left.4.98 \mu \mathrm{mol} \mathrm{kg}{ }^{-1}\right)$, statistically improves the MLR fit to the DIC concentrations relative to regressions using only a subset of the variables.

[21] Two types of MLR analyses have been used to estimate $\Delta C_{\text {anthro }}$ (equation (5)). The MLR method most commonly used by previous studies [Goyet and Davis, 1997; Peng, 2005; Peng et al., 2003; Sabine et al., 1999; Wallace, 1995] uses the MLR parameters fit at time $t_{0}, p\left(t_{0}\right)$, and the data from time $t_{1}$, data $\left(t_{1}\right)$, to compute $C^{\mathrm{MLR}}\left(t_{1}\right)$. The estimated DIC concentration for $t_{1}$ is then differenced from the observations at $t_{1}$ :

$$
\Delta C_{\text {anthro }}^{\mathrm{MLR}}=C_{\mathrm{obs}}\left(t_{1}\right)-C^{\mathrm{MLR}}\left[p\left(t_{0}\right), \operatorname{data}\left(t_{1}\right)\right] .
$$

The extended multiple linear regression analysis (eMLR), introduced by Friis et al. [2005], replaces the DIC observations at time $t_{1}$ with a second MLR estimate using parameters and data from $t_{1}$.

$$
\Delta C_{\mathrm{anthro}}^{\mathrm{eMLR}}=C^{\mathrm{MLR}}\left[p\left(t_{1}\right), \operatorname{data}\left(t_{1}\right)\right]-C^{\mathrm{MLR}}\left[p\left(t_{0}\right), \operatorname{data}\left(t_{1}\right)\right] .
$$

[22] The eMLR method results in a much smoother

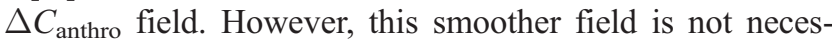
sarily more realistic. The MLR (equation (8)) represents only that fraction of the total DIC variance that projects linearly onto the chosen physical and biogeochemical variables; the remaining variance falls into the regression residuals,

$$
C_{\mathrm{resid}}^{\mathrm{MLR}}\left(t_{i}\right)=C_{\mathrm{obs}}\left(t_{i}\right)-C^{\mathrm{MLR}}\left[p\left(t_{i}\right), \operatorname{data}\left(t_{i}\right)\right]
$$

which include both random noise and real geochemical signals. By analyzing the components of the MLR individually, we find that the MLR variables are highly correlated, leading to large cancellations between the terms in equation (8). Substantial coherence between the MLR variables indicates that they are nonorthogonal and so poor basis functions for DIC. Coherence increases the likelihood that real DIC signals will not be mapped onto the MLR variables, and therefore potentially valuable information will be left in the residuals. 
Table 1. Mean, Mode, and Maximum of Model DIC RMS Variability $(1 \sigma)$ for Model DIC Output and the $\Delta C^{*}$, MLR, and eMLR Techniques $^{\mathrm{a}}$

\begin{tabular}{lcccc}
\hline & & \multicolumn{2}{c}{ RMS } \\
\cline { 2 - 5 } \multicolumn{1}{c}{ Method } & Mean $(0-2000 \mathrm{~m})$ & Mean $(200-2000 \mathrm{~m})$ & Mode & Max $(0-2000 \mathrm{~m})$ \\
\hline DIC Output & 4.59 & 2.29 & 0.62 & 23.37 \\
$\Delta C^{*}$ & 1.88 & 1.22 & 0.27 & 14.16 \\
MLR & 3.55 & 0.88 & 0.28 & 53.83 \\
eMLR & 0.65 & 0.31 & 0.16 & 6.51 \\
\hline
\end{tabular}

${ }^{a}$ DIC, dissolved inorganic carbon; MLR, multiple linear regression; eMLR, extended multiple linear regression analysis. The $1 \sigma$ values are calculated using years 101-450 of the 1000 year CSM1.4 control run extracted along the A16 transect, and they are measured in $\mu$ mol kg ${ }^{-1}$. Mode and mean values are based on grid cell values. As the empirical estimates are not robust above $200 \mathrm{~m}$, the mean and maximum values for $200-2000 \mathrm{~m}$ are also given. The mode is representative of the deep ocean variability.

[23] The difference between the $\Delta C_{\text {anthro }}^{\mathrm{MLR}}$ (equation (9)) and $\Delta C_{\text {anthro }}^{\mathrm{eMLR}}$ (equation (10)) fields equals the MLR residuals for time $t_{1}$,

$$
\begin{aligned}
\Delta C_{\text {anthro }}^{\mathrm{MLR}}-\Delta C_{\mathrm{anthro}}^{\mathrm{eMLR}} & =C_{\mathrm{obs}}\left(t_{1}\right)-C^{\mathrm{MLR}}\left[p\left(t_{1}\right), \operatorname{data}\left(t_{1}\right)\right] \\
& =C_{\text {resid }}^{\mathrm{MLR}}\left(t_{1}\right) .
\end{aligned}
$$

The eMLR field is smoother because the "noise" of the residuals has been removed. Any coherent pattern in the residuals can lead to biases in the MLR estimate of $\Delta C_{\text {anthro }}$. The traditional MLR estimate of anthropogenic $\mathrm{CO}_{2}$ is biased because the MLR residuals from $t_{0}, C_{\text {resid }}^{\mathrm{MLR}}\left(t_{0}\right)$, are incorporated into the estimate of $\Delta C_{\text {anthro }}^{\mathrm{MLR}}$ The eMLR is biased because it assumes that $C_{\text {resid }}^{\mathrm{MLR}}\left(t_{1}\right)$ and $C_{\text {resid }}^{\mathrm{MLR}}\left(t_{0}\right)$ will cancel. This assumption is difficult to justify as the residual fields are quite sensitive to the different regression parameters at the different times. These biases are inherent to the MLR technique and so apply to estimates of $\Delta C_{\text {anthro }}^{\mathrm{MLR}}$ and $\Delta C_{\text {anthro }}^{\mathrm{eMLR}}$ for both the model simulations and field observations.

\subsection{Upper Water Column Variability}

[24] High seasonal variability in the upper water column makes it difficult to detect changes in anthropogenic carbon inventories in this region. Both the $\Delta C^{*}$ and MLR methods have known issues in the upper $200 \mathrm{~m}$ leading to less reliable estimates of $\Delta C_{\text {anthro }}$ [e.g., Matsumoto and Gruber, 2005; Wallace, 1995]. To avoid errors introduced by seasonal variability and to maintain consistency with the typical application of the $\Delta C^{*}$ and MLR methods, we focus our analysis on the region below $200 \mathrm{~m}$. For the decade under study (average atmospheric $\mathrm{CO}_{2}$ of $375 \mathrm{ppm}$ ), very little anthropogenic carbon has penetrated below
$2000 \mathrm{~m}$; hence we further limit our focus region to $200-$ $2000 \mathrm{~m}$. Tables 1 and 2 present results for both the $1-2000$ $\mathrm{m}$ and 200-2000 $\mathrm{m}$ intervals. Inclusion of the upper $200 \mathrm{~m}$ significantly increases both the DIC RMS $1 \sigma$ value for the control run, a measure of the natural variability in the system, and the RMS difference between the estimated and predicted $\Delta C_{\text {anthro }}$ values. This confirms that the upper water column has increased variability and that empirical methods are not robust in this region. Unless otherwise stated, all further analysis will be done for the $200-2000 \mathrm{~m}$ depth range, including all anthropogenic carbon inventory calculations.

\section{Removing Natural Variability in the Model Ocean Carbon System}

[25] The primary function of empirical methods like $\Delta C^{*}$ and MLR is to remove the natural variability of the carbon system in order to reveal the underlying anthropogenic signal. To characterize the interannual to decadal variability in the model, we calculate the DIC RMS variability for the CSM1.4 model control run using mean monthly output. A 350 year period which spans the two transient runs is used for this analysis (control run years 101 to 450). For each model grid cell, the data are detrended by removing the model drift using a low-pass filter and by removing the average seasonal cycle. Figure 2 a shows a contour plot of the DIC $1 \sigma$ values for the section. The mean DIC RMS variability is $\pm 4.59 \mu \mathrm{mol} \mathrm{kg} \mathrm{kg}^{-1}(1 \sigma, 0-2000 \mathrm{~m})$ or $2.29 \mu \mathrm{mol} \mathrm{kg}^{-1}(1 \sigma, 200-2000 \mathrm{~m})$. The mode of the RMS variability for the entire transect, representative of the RMS variability in the deep ocean, is $\pm 0.62 \mu \mathrm{mol} \mathrm{kg}{ }^{-1}$. The surface ocean and high-latitude North Atlantic are regions

Table 2. Comparison of Anthropogenic Techniques Showing the Mean, Mode, and Maximum of the Predicted Model $\Delta C_{\text {anthro }}$ and the

\begin{tabular}{|c|c|c|c|c|c|c|c|}
\hline \multirow[b]{2}{*}{ Method } & \multicolumn{4}{|c|}{ Anthropogenic Increase } & \multicolumn{3}{|c|}{ RMS, Estimated - Predicted } \\
\hline & Mean $(0-2000 \mathrm{~m})$ & Mean $(200-2000 \mathrm{~m})$ & $\operatorname{Max}(0-2000 \mathrm{~m})$ & $\operatorname{Max}(200-2000 \mathrm{~m})$ & Whole Section & $0-2000 \mathrm{~m}$ & $200-2000 \mathrm{~m}$ \\
\hline Predicted $\Delta C_{\text {anthro }}$ & 5.48 & 3.02 & 15.22 & 12.75 & & & \\
\hline$\Delta C^{*}$ & 4.71 & 3.11 & 20.43 & 15.78 & 2.24 & 2.36 & 1.58 \\
\hline$\Delta C^{*}$ Using $\mathrm{PO}_{4}$ & 4.48 & 3.16 & 25.45 & 17.04 & 4.15 & 4.19 & 2.59 \\
\hline MLR & 9.01 & 3.29 & 96.93 & 32.43 & 12.50 & 13.49 & 5.04 \\
\hline eMLR & 6.51 & 2.76 & 24.89 & 11.64 & 3.21 & 3.60 & 1.50 \\
\hline
\end{tabular}
$\Delta C_{\text {anthro }}$ Estimates $^{\mathrm{a}}$

${ }^{\mathrm{a}}$ Results were calculated using the $\Delta C^{*}, \Delta C_{\mathrm{PO}}^{*}$, MLR, and eMLR techniques and measured in $\mu \mathrm{mol} \mathrm{kg}^{-1} . \Delta C_{\text {anthro }}$ values are calculated for a 10 year period with an average atmospheric $\mathrm{CO}_{2}$ of $375 \mathrm{ppm}$ using mean monthly model output extracted along the A16 transect. The RMS error for each estimate relative to $\Delta C_{\text {anthro }}^{\text {predicte }}$ is also given. 

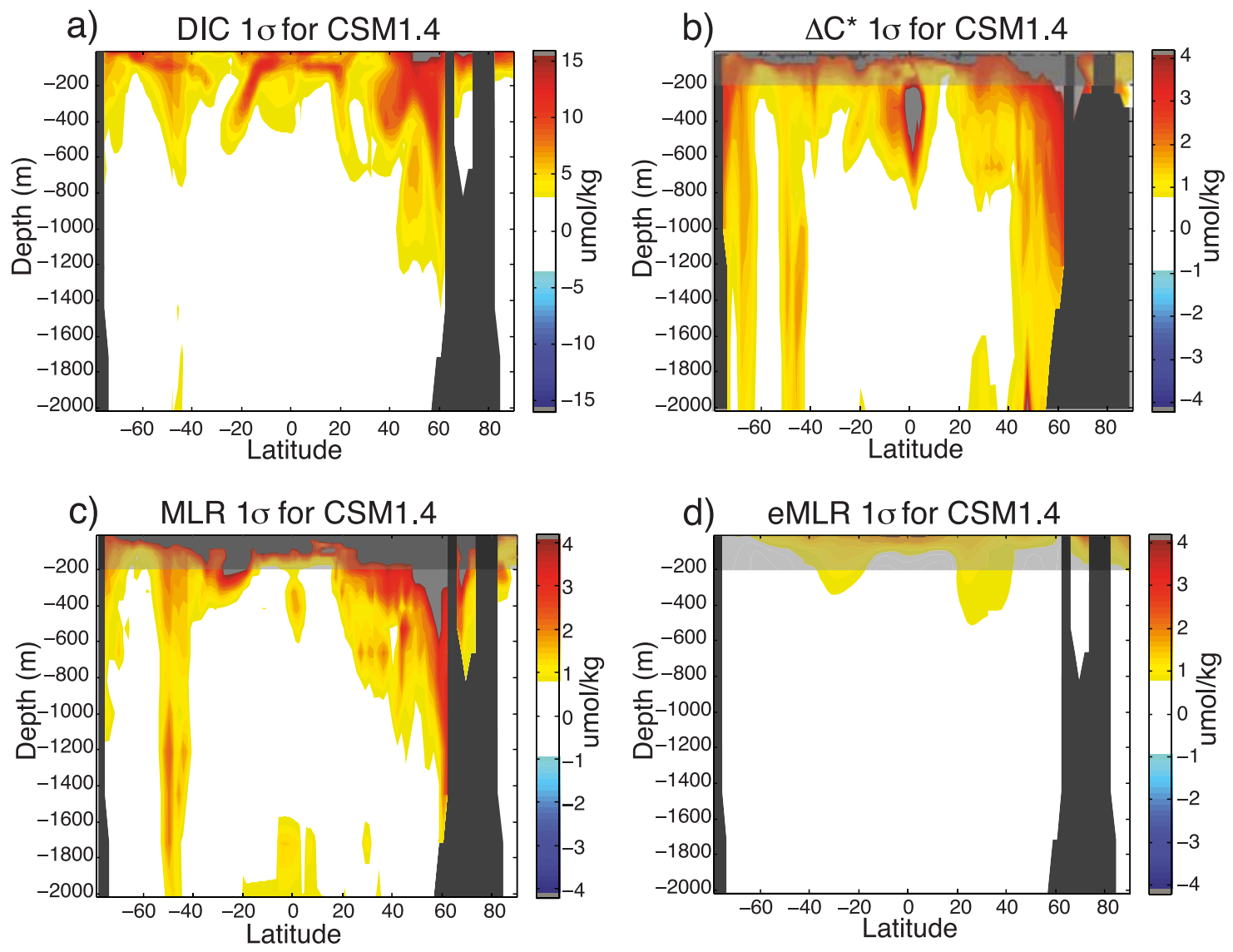

Figure 2. Depth profiles of CSM1.4 model output along the A16 transect showing RMS variability $(1 \sigma)$ for (a) model dissolved inorganic carbon (DIC) output, (b) $\Delta C^{*}$, (c) multiple linear regression (MLR), and (d) extended multiple linear regression (eMLR) calculated using years 101-450 of the 1000 year control run. $\Delta C^{*}$ is calculated in isopycnal space and projected back into depth space. Note the difference in scale in model DIC output.

of high variability, with $1 \sigma$ values reaching $\pm 23.37 \mu \mathrm{mol}$ $\mathrm{kg}^{-1}(0-2000 \mathrm{~m})$.

[26] To determine the processes driving these large natural shifts in DIC, we examine the correlation between DIC anomalies and physical (temperature, salinity, and air-sea gas exchange) and biogeochemical (oxygen, phosphorous, export production) properties. We analyze the properties controlling the month to month evolution of DIC using property-property plots and covariance and multiple linear regression analysis. The near-surface variability, particularly at high latitudes, is driven by vertical or lateral shifts in the boundary between water masses and by changes in water mass air-sea disequilibrium. A histogram of the mean monthly variance (not shown) exhibits high variability in the North Atlantic Deep Water, and mode water formation region, $40^{\circ} \mathrm{N}-60^{\circ} \mathrm{N}$, is driven by large anomalies in the spring following the winter convection period. Finally, a spectral analysis indicates that interannual and decadal scale variability in subpolar regions is modulated on centennial timescales by model climate state; the interannual to decadal variability in subtropics and tropics is more uniform over the simulation.

[27] We evaluate the ability of the $\Delta C^{*}$ method to remove the natural variability in the model carbon cycle by calculating a spatial map of RMS $\Delta C^{*}$ for the monthly outputs over a 350 year period of the control run. Nonzero $1 \sigma$ values reflect either errors in the $\Delta C^{*}$ construct or changes in air-sea disequilibrium $\left(C_{\mathrm{diseq}}\right)$. The $\Delta C^{*}$ method is able to reduce but not fully eliminate the natural variability in surface waters, at the equator, and in the North Atlantic Deep Water formation region, indicating areas where potential biases may arise in $\Delta C_{\text {anthro }}^{C^{*}}$ (Figure $2 \mathrm{~b}$ ). We perform a similar test of the two MLR techniques, calculating maps of RMS $\Delta C^{\mathrm{MLR}}$ and $\Delta C^{\mathrm{eMLR}}$ for the same model time period. The baseline MLR parameters $p\left(t_{0}\right)$ (equation (8)) are computed using the mean DIC, nutrient, and physical fields. For the 200-2000 m region the MLR and eMLR reduce the natural RMS variability of the inorganic carbon system by 2.5 - and 7-fold, respectively, a greater reduction than is achieved using the $\Delta C^{*}$ method (Table 1). However, direct comparison of the MLR, eMLR, and $\Delta C^{*}$ RMS values may be somewhat misleading as the MLR regressions do not capture all of the variance of original fields, as discussed in section 3.2. The highest $1 \sigma$ MLR and eMLR values are observed in the upper $200 \mathrm{~m}$ (Figures $2 \mathrm{c}$ and $2 \mathrm{~d}$ ), where the MLR technique is not robust. Similar to the $\Delta C^{*}$ method, the MLR displays high $1 \sigma$ values in the North Atlantic Deep Water formation region, indicating that the $\Delta C_{\text {anthro }}^{\mathrm{MLR}}$ estimate will most likely be biased for this region because the MLR fit does not capture 
a substantial amount of the natural variability. The mean, maximum, and mode $1 \sigma$ values for the control run, and the $\Delta C^{*}$ method, and the MLR techniques are presented in Table 1 .

\section{Detection and Attribution of Temporal Trends in Anthropogenic $\mathrm{CO}_{2}$}

[28] The ability of the $\Delta C^{*}$ and the MLR techniques to accurately estimate $\Delta C_{\text {anthro }}$ is tested by comparing the empirical estimates of the temporal change of anthropogenic $\mathrm{CO}_{2}\left(\Delta C_{\text {anthro }}^{C^{*}}, \Delta C_{\text {anthro }}^{\mathrm{MLR}}\right.$, and $\left.\Delta C_{\text {anthro }}^{\mathrm{eMLR}}\right)$ to the predicted value for transient simulations, $\Delta C_{\text {anthro }}^{\text {predicted }}$. This comparison is done for a 10 year period for which average Northern Hemisphere atmospheric $\mathrm{CO}_{2}$ is approximately $375 \mathrm{ppm}$ (GLOBALVIEW-CO2 data are available at ftp://ftp.cmdl. noaa.gov/ccg/co2/GLOBALVIEW). The following analysis highlights issues and potential biases in the two techniques. However, the magnitude of the errors for actual field data may differ somewhat because of errors, such as sampling and analytical errors, that are not accounted for in the model.

[29] Similar to observations from repeat hydrography cruises [e.g., Wanninkhof et al., 2006a], the natural variability in the ocean carbon system leads to spatial noise in the plot of $\triangle \mathrm{DIC}$ for any particular occupation (Figure 3a). This "snapshot" change in DIC differs substantially from the predicted invasion of anthropogenic $\mathrm{CO}_{2}, \Delta C_{\text {anthro }}^{\text {predicted }}$ (Figure 4a), which is calculated using the low-pass filter as described in section 2. The RMS error of the estimated $\Delta C_{\text {anthro }}$ values from the predicted value is given by

$$
\sigma=\sqrt{\frac{\sum\left(\Delta C_{\text {anthro }}^{\text {estimate }}-\Delta C_{\text {anthro }}^{\text {predicted }}\right)^{2}}{(N-1)}},
$$

where $N$ is the number of values being compared. The RMS error for each technique is given in Table 2. Figures $4 b, 4 c$, and $4 \mathrm{~d}$ show the difference between $\Delta C_{\text {anthro }}^{\text {predicted }}$ and $\Delta C_{\text {anthro, }}^{C^{*}}, \Delta C_{\text {anthro, }}^{\mathrm{MLR}}$, and $\Delta C_{\text {anthro }}^{\mathrm{MLR}}$, respectively. The average percent error is calculated as

$$
\% \text { error }=\frac{\left|\Delta C_{\text {anthro }}-\Delta C_{\text {anthro }}^{\text {predicted }}\right|}{\Delta C_{\text {anthro }}^{\text {predicted }}} \times 100
$$

using only points with significant anthropogenic carbon, $\Delta C_{\text {anthro }}^{\text {predicted }} \geq 3 \mu \mathrm{mol} \mathrm{kg}^{-1}$ per decade. The average percent error for decadal differences for the MLR, eMLR, and $\Delta C^{*}$ methods are $82.0 \%, 25.5 \%$, and $24.1 \%$, respectively. These errors are consistent with previous error estimates for these techniques [Friis et al., 2005; Gruber et al., 1996]. While the average errors for the eMLR and $\Delta C^{*}$ techniques are similar, the distribution of the errors differ substantially. The eMLR errors are evenly distributed over the entire transect, whereas the $\Delta C^{*}$ method performs better overall but has regions with extremely large deviations from $\Delta C_{\text {anthro }}^{\text {predicted }}$.

[30] The $\Delta C^{*}$ method is able to account for the majority of the natural variability in the system and provides a fairly accurate estimate of anthropogenic $\mathrm{CO}_{2}$ at low latitudes and midlatitudes $\left(40^{\circ} \mathrm{S}-30^{\circ} \mathrm{N}\right)$. However, at the high latitudes, $\Delta C_{\text {anthro }}^{C^{*}}$ differs from the predicted value by up
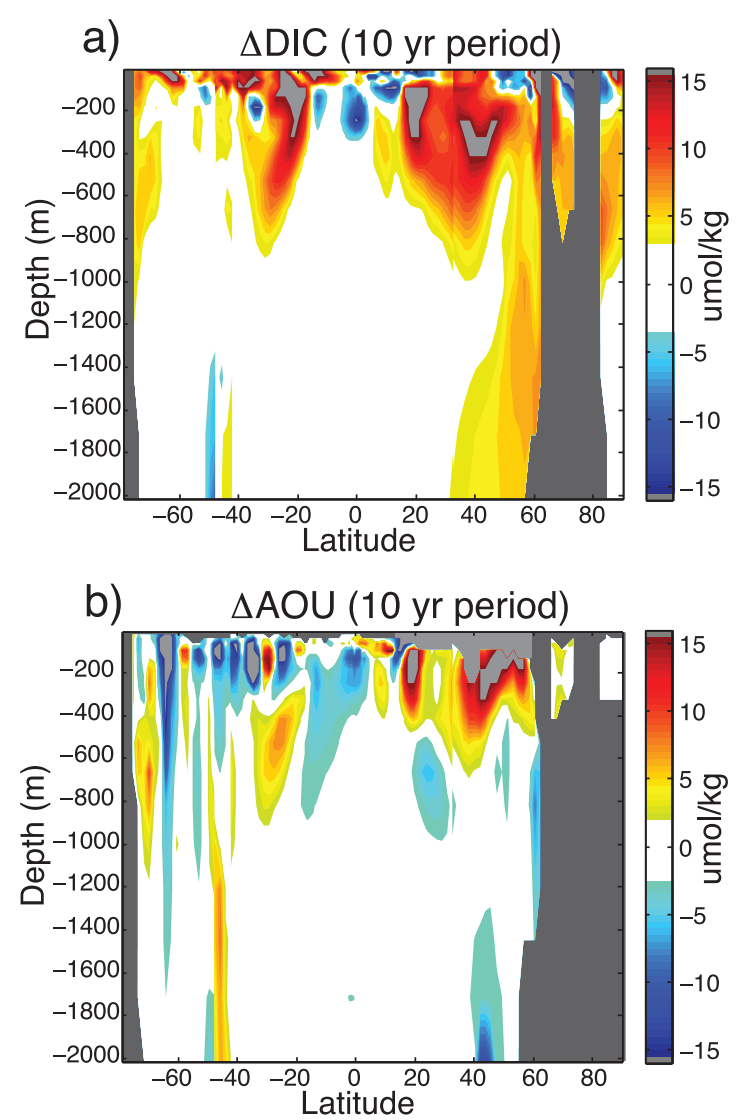

Figure 3. Depth profiles of CSM1.4 model output along the A16 transect showing (a) the "snapshot" change in DIC and (b) the change in apparent oxygen utilization (AOU) for a 10 year period with an average atmospheric $\mathrm{CO}_{2}$ of 375 ppm. $\triangle \mathrm{AOU}$ is calculated in isopycnal space and projected back into depth space.

to $11 \mu \mathrm{mol} \mathrm{kg} \mathrm{kg}^{-1}$. These errors are large relative to the mean and maximum predicted anthropogenic signal $\left(\Delta C_{\text {anthro }}^{\text {predicted }}(\right.$ mean $)=3.02 \mu \mathrm{mol} \mathrm{kg} \mathrm{kg}^{-1}$ and $\Delta C_{\text {anthro }}^{\text {pred }}$ $\left.(\max )=12.75 \mu \mathrm{mol} \mathrm{kg} \mathrm{kg}^{-1}\right)$. This discrepancy could be due to either errors in the $\Delta C^{*}$ construct or in the assumptions made about the constancy of the air-sea disequilibrium term $\left(C_{\text {diseq }}\right)$ along isopycnal surfaces.

[31] We look at changes in temperature, salinity, phosphorus, and oxygen over the 10 year study period to explain the discrepancy between $\Delta C_{\text {anthro }}^{C^{*}}$ and $\Delta C_{\text {anthro }}^{\text {predicted }}$ at high latitudes. While temperature, salinity, and phosphorus exhibit only small changes over this time period, there are large changes in apparent oxygen utilization $(\mathrm{AOU}=$ $\mathrm{O}_{2}^{\text {sat }}-\mathrm{O}_{2}$ ) (Figure 3b). At high latitudes, areas with large changes in AOU correlate well with regions in which $\Delta C_{\text {anthro }}^{C^{*}}$ deviates from $\Delta C_{\text {anthro }}^{\text {predicted }}$. In particular, large positive changes in AOU are associated with $\Delta C^{*}$ underestimating the increase in anthropogenic $\mathrm{CO}_{2}$. Figure 5 shows the strong correlation between $\Delta C_{\text {anthro }}^{\text {predicted }}-$ $\Delta C_{\text {anthro }}^{C^{*}}$ and $\triangle \mathrm{AOU}$ for the high latitudes $\left(40^{\circ} \mathrm{S}-70^{\circ} \mathrm{S}\right.$ and $30^{\circ} \mathrm{N}-90^{\circ} \mathrm{N}$ ). Both $\Delta C_{\text {anthro }}^{C^{*}}$ and $\triangle \mathrm{AOU}$ are calculated using mean monthly model output in isopycnal space and then mapped back into depth space. 

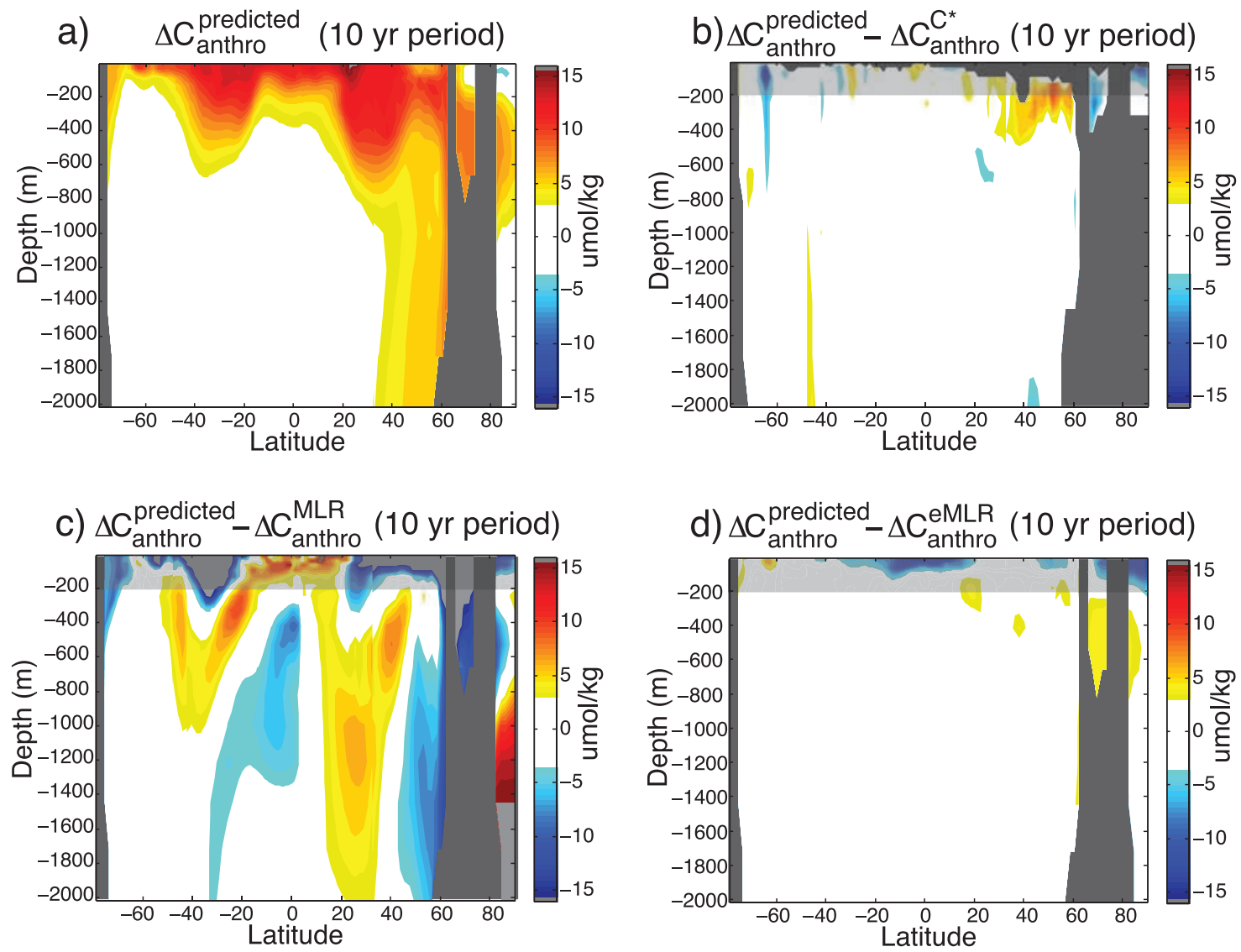

Figure 4. Depth profiles of CSM1.4 model output along the A16 transect showing (a) $\Delta C_{\text {anthro }}^{\text {predicted in }}$ $\mu$ mol kg k ${ }^{-1}$ (b) the difference between $\Delta C_{\text {anthro }}^{\text {predicted }}$ and $\Delta C_{\text {anthro, }}^{C^{*}}$ (c) the difference between $\Delta C_{\text {anthro }}^{\text {predicted }}$

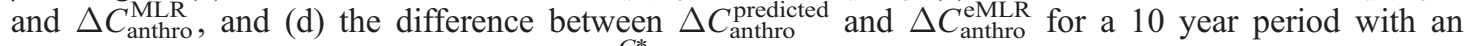
average atmospheric $\mathrm{CO}_{2}$ of $375 \mathrm{ppm} . \Delta C_{\text {anthro }}^{C^{*}}$ is calculated in isopycnal space and projected back into depth space. The upper $200 \mathrm{~m}$ are shaded as the $\Delta C_{\text {anthro }}$ estimates in this region are not robust.

[32] In the case where the $\Delta C^{*}$ method reproduces the predicted $\Delta C_{\text {anthro }}$ signal, the data points in a plot of $\Delta C_{\text {anthro }}^{\text {predicted }}-\Delta C_{\text {anthro }}^{C^{*}}$ versus $\Delta \mathrm{AOU}$ will fall along the $x$ axis (represented by the light gray line in Figure 5). Movement along this line is caused by changes in $C_{\mathrm{bio}}$ (equation (2)), where increases in $C_{\text {bio }}$ move data points to the right and decreases in $C_{\text {bio }}$ move points to the left (represented by the light gray arrow in Figure 5). Deviations from this ideal case are caused by changes in $\mathrm{O}_{2}$ and DIC air-sea disequilibrium, for DIC represented by the $C_{\text {diseq }}$ term (equation (3)). The $\Delta C^{*}$ method assumes that oxygen is always saturated in surface waters and therefore incorrectly attributes $\mathrm{O}_{2}$ air-sea disequilibrium (nonzero surface AOU values) to biologic activity. An increase in AOU disequilibrium, water leaving the surface with less $\mathrm{O}_{2}$ and a higher AOU, is thus treated as an increase in biologic activity and results in an underestimate of $\Delta C_{\text {anthro, }}$, and vice versa. This moves data points off of the $x$ axis with a slope of $r_{\mathrm{C}: \mathrm{AOU}}, 117: 170$, (represented by the black arrow in Figure 5). The $\Delta C^{*}$ method also assumes that the preindustrial DIC air-sea disequilibrium remains constant with time; $C_{\text {diseq }}\left(t_{1}\right)-C_{\text {diseq }}\left(t_{0}\right)$ from equation (7) equals zero, as discussed above. Therefore an increase in $C_{\text {diseq }}$, water leaving the surface with more DIC, will result in an overestimate of $\Delta C_{\text {anthro }}$ and vice versa. This moves data points in the $\Delta C_{\text {anthro }}^{\text {predited }}-\Delta C_{\text {anthro versus }}^{C^{*}} \Delta$ AOU plot vertically (represented by the dark gray arrow in Figure 5). The best fit line in Figure 5 (plotted as a dashed black line) is therefore an amalgamation of the AOU disequilibrium line (the black arrow) and the $\Delta C_{\text {diseq }}$ line (the dark gray arrow). We conclude that the majority of the discrepancy between $\Delta C_{\text {anthro }}^{C^{*}}$ and $\Delta C_{\text {anthro }}^{\text {predicted }}$ at high latitudes is due to variability in $\mathrm{AOU}$ disequilibrium in the surface waters, which is not accurately accounted for by the $\Delta C^{*}$ method. This bias is partially offset by changes in the $\Delta C_{\text {diseq }}$ term, which is also not accounted for by the $\Delta C^{*}$ method. These findings are similar to the findings of Wanninkhof et al. [2006a].

[33] The bias in the $\Delta C^{*}$ calculation due to $\mathrm{O}_{2}$ air-sea disequilibrium can be eliminated by using $\mathrm{PO}_{4}$ instead of $\mathrm{O}_{2}$ to correct for changes in the biologic pump [Gruber and Sarmiento, 2002]. This can be accomplished by substituting the change in phosphorus, $r_{\mathrm{C}: \mathrm{PO}}\left(\mathrm{PO}_{4}^{0}-\mathrm{PO}_{4}\right)$ where $\mathrm{PO}_{4}^{0}$ is preformed $\mathrm{PO}_{4}$, for $r_{\mathrm{C}: \mathrm{O} 2}\left(\mathrm{O}_{2}^{\text {sat }}-\mathrm{O}_{2}\right)$ in equation (6). Unfortunately, this substitution introduces a new set of difficulties. Namely, we do not have a direct method for 
Changes in Air-Sea Disequilibrium

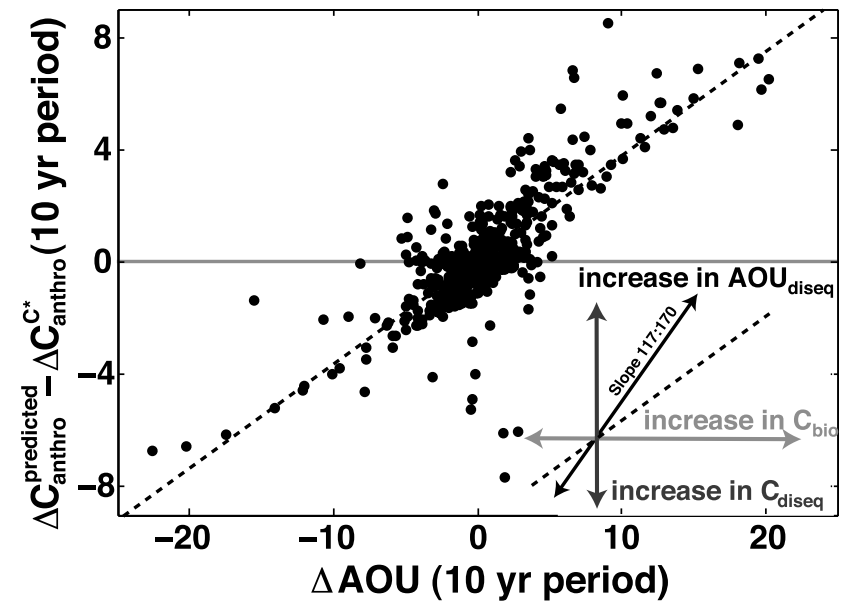

Figure 5. Correlation between model $\left(\Delta C_{\text {anthro }}^{\text {predict }}-\right.$ $\Delta C_{\text {anthro }}^{C^{*}}$ and $\triangle$ AOU for a 10 year period with an average atmospheric $\mathrm{CO}_{2}$ of 375 ppm caused by changes in air-sea disequilibrium. Only data between 200 and $2000 \mathrm{~m}$ and at the high latitudes $\left(40^{\circ} \mathrm{S}-70^{\circ} \mathrm{S}, 30^{\circ} \mathrm{N}-90^{\circ} \mathrm{N}\right)$ are displayed. $\triangle \mathrm{AOU}$ and $\Delta C_{\text {anthro }}^{C^{*}}$ are calculated in isopycnal space and projected back into depth space. If the $\Delta C^{*}$ method reproduced the predicted $\Delta C_{\text {anthro }}$ signal exactly, the data points would all fall along the $x$ axis, the horizontal gray line. Since the $\Delta C^{*}$ method accounts for changes in $C_{\text {bio, }}$, increases in $C_{\text {bio }}$ simply move data points horizontally to the right (light gray arrow). Deviations from the $x$ axis are caused by changes in $C_{\text {diseq }}$ and $\mathrm{AOU}_{\text {diseq }}$ which move data points off the $x$ axis vertically (dark gray arrow) and with a slope of $r_{\mathrm{C}: \mathrm{AOU}}, 117: 170$ (the black arrow), respectively. The best fit line is plotted as a dashed black line and represents an amalgamation between changes in $\mathrm{AOU}_{\text {diseq }}$ and $C_{\text {diseq }}$.

determining $\mathrm{PO}_{4}^{0}$. Hydrographic surveys also face the problem that the fractional uncertainties for $\mathrm{PO}_{4}$ measurements are high, and studies have shown that $\mathrm{C}: \mathrm{P}$ ratios vary with depth because of preferential remineralization of phosphorus [e.g., Martin et al., 1987]. Here we estimate $\Delta C_{\text {anthro }}$ using $\Delta C_{\text {anthro }}^{\mathrm{C}_{4}^{*}}$ by assuming that $\mathrm{PO}_{4}^{0}$ remains constant along isopycnal surfaces and therefore cancels in the calculation of $\Delta C_{\text {anthro }}^{C_{\mathrm{PO}_{4}}^{*}}$. Because of the inaccuracies of this assumption, the $\Delta C_{\text {anthro }}^{C_{\mathrm{PO}_{4}}^{*}}$ estimate still differs significantly from $\Delta C_{\text {anthro }}^{\text {predicted }}$

(Table 2).

[34] For the same 10 year period we calculate $\Delta C_{\text {anthro }}$ using both the MLR and the eMLR techniques. The MLR coefficients and their $1 \sigma$ errors for $t_{0}\left(\right.$ time $\left._{0}\right)$ and $t_{1}\left(\right.$ time $\left._{1}\right)$
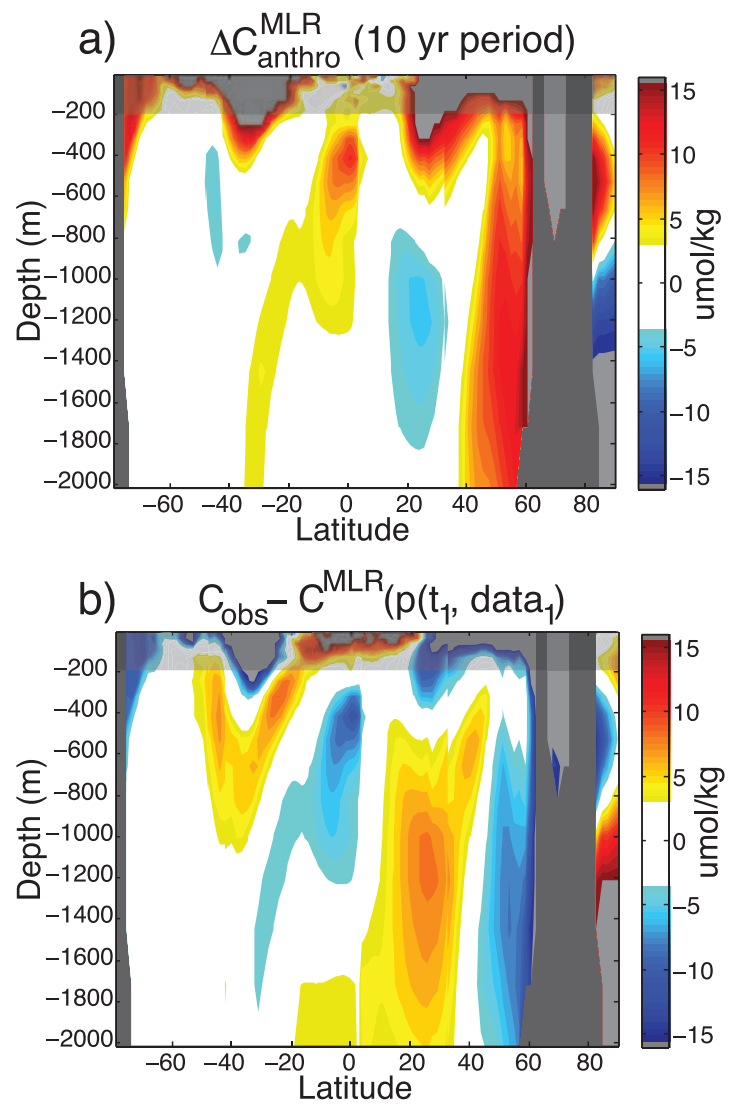

Figure 6. Depth profiles of CSM1.4 model output along the A16 transect showing (a) $\Delta C_{\text {anthro }}$ calculated using the MLR technique for a 10 year period with an average atmospheric $\mathrm{CO}_{2}$ of $375 \mathrm{ppm}$ and (b) the model MLR residuals for time ${ }_{1}\left(t_{1}\right)$. The upper $200 \mathrm{~m}$ are shaded as the $\Delta C_{\text {anthro }}$ estimates in this region are not robust.

are given in Table 3. The residual error for the MLR fit to the model DIC concentrations at $\mathrm{t}_{0}$ is $\pm 4.98 \mu \mathrm{mol} \mathrm{kg}^{-1}\left(r^{2}=\right.$ $0.990, \mathrm{n}=1194)$ and at $t_{1}$ is $\pm 5.81 \mu \mathrm{mol} \mathrm{kg}{ }^{-1}\left(r^{2}=0.985\right.$, $\mathrm{n}=1194)$. These errors are approximately the same as the residual error for MLR fits to field observations, $\sim 6 \mu \mathrm{mol} \mathrm{kg}^{-1}$ [Brewer et al., 1995; Friis et al., 2005]. However, the model MLR residual error is most likely small because of a tight correlation between changes in $\mathrm{PO}_{4}$ concentration and biologic activity in the model. For field observations, including either nitrate or silicate as MLR parameters is often necessary to obtain a low residual error [Brewer et al., 1995; Friis et al., 2005]. As neither nitrate nor silicate is tracked in the model, we are forced to use only oxygen and phosphorus as biological variables.

Table 3. MLR Parameters ${ }^{\mathrm{a}}$

\begin{tabular}{|c|c|c|c|c|c|c|c|}
\hline & $r^{2}$ & RMSE, $\mu \mathrm{mol} \mathrm{kg}{ }^{-1}$ & Intercept & $\Theta$ & $\mathrm{S}$ & $\mathrm{O}_{2}$ & $\mathrm{PO}_{4}$ \\
\hline Time $_{0}$ & 0.9903 & 4.98 & $400.39 \pm 21.83$ & $-4.26 \pm 0.10$ & $49.26 \pm 0.58$ & $-0.23 \pm 0.01$ & $77.22 \pm 0.86$ \\
\hline Time $_{1}$ & 0.9854 & 5.81 & $456.02 \pm 25.76$ & $-3.36 \pm 0.11$ & $47.75 \pm 0.68$ & $-0.19 \pm 0.01$ & $77.61 \pm 1.02$ \\
\hline
\end{tabular}

${ }^{\mathrm{a}}$ The $r^{2}$ values, root-mean-square-error (RMSE), MLR parameters, and the parameter $1 \sigma$ errors for the MLR fit to model output at time ${ }_{0}\left(t_{0}\right)$ and time ${ }_{1}$ $\left(t_{1}\right)$, where $t_{1}-t_{0}$ is a 10 year period with an average atmospheric $\mathrm{CO}_{2}$ of $375 \mathrm{ppm}$. 


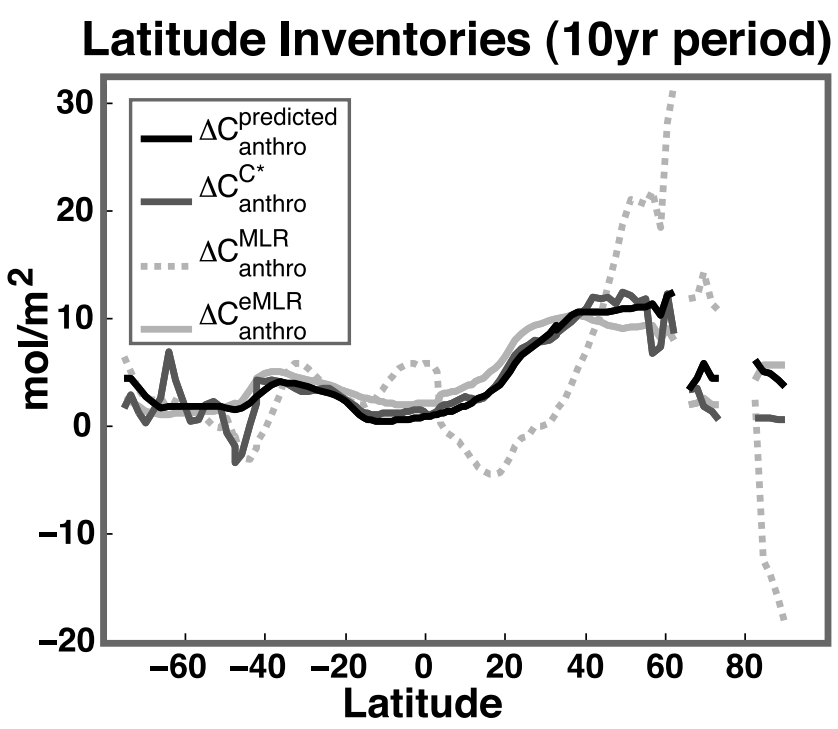

Figure 7. Comparison between predicted model column inventory $(200-2000 \mathrm{~m})$ of $\Delta C_{\text {anthro }}$ and latitude inventories (200-2000 m) of $\Delta C_{\text {anthro }}$ calculated using the $\Delta C^{*}$, MLR, and eMLR techniques for model output extracted along the A16 transect. Inventories are for a 10 year period with an average atmospheric $\mathrm{CO}_{2}$ of $375 \mathrm{ppm}$.

[35] While $\Delta C_{\text {anthro accurately reproduces the spatial }}^{\mathrm{MLR}}$ distribution of anthropogenic $\mathrm{CO}_{2}$ along the section, it significantly overestimates the magnitude of the predicted signal by greater than $15 \mu \mathrm{mol} \mathrm{kg}{ }^{-1}$ in the upper $2000 \mathrm{~m}$ (Figures $6 \mathrm{a}$ and $4 \mathrm{c}$ ). The RMS error of $\Delta C_{\mathrm{anthr}}^{\mathrm{MLR}}$ relative to $\Delta C_{\text {anthro }}^{\text {predicted }}$ is $5.04 \mu \mathrm{mol} \mathrm{kg}^{-1}$, significantly greater than all other empirical methods tested in this study (Table 2). This error is caused by large MLR residuals that bias the $\Delta C_{\mathrm{anthr}}^{\mathrm{MLR}}$ estimate, as discussed above. The residuals for the MLR fit to $t_{1}$ are shown in Figure 6b. By subtracting the MLR $t_{1}$ residuals from the $\Delta C_{\text {anthro }}^{\mathrm{MLR}}$ estimate, one arrives at $\Delta C_{\text {anthro }}^{\mathrm{eMLR}}$ (equation (12)), which better matches $\Delta C_{\text {anthro }}^{\text {predicted }}$. The difference between $\Delta C_{\text {anthro }}^{\text {predicted }}$ and $\Delta C_{\text {anthro }}^{\mathrm{eMLR}}$ is shown in Figure $4 \mathrm{~d}$. The eMLR estimate displays both the same spatial distribution and magnitude as the predicted signal. However, as discussed above, the eMLR method produces a biased $\Delta C_{\text {anthro }}$ estimate when there is structure in the MLR residuals.

\section{Effects on Inventories}

[36] Estimates of anthropogenic carbon are most frequently presented as either column, basin, or global inventories with different methods providing significantly different inventory estimates. Here we compare the predicted temporal change in the column inventory calculated from $\Delta C_{\text {anthro }}^{\text {predicted }}$ to the column inventories calculated from the $\Delta C_{\text {anthro }}^{C^{*}}, \Delta C_{\text {anthro }}^{\mathrm{MLR}}$, and $\Delta C_{\text {anthro }}^{\mathrm{eMLR}}$ estimates for the model output extracted along the A16 transect for a decade approximately equal to 2000-2010 (Figure 7). The MLR inventory estimates deviate significantly from the predicted inventory for the majority of the section with the largest overestimate occurring in the North Atlantic between $40^{\circ} \mathrm{N}$ and $60^{\circ} \mathrm{N}$ and the largest underestimate occurring between $0^{\circ} \mathrm{N}$ and $40^{\circ} \mathrm{N}$ and $>80^{\circ} \mathrm{N}$. The $\Delta C^{*}$ and eMLR methods more accurately reproduce the predicted inventory. At low latitudes and midlatitudes $\left(40^{\circ} \mathrm{S}-40^{\circ} \mathrm{N}\right)$ the $\Delta C^{*}$ inventory matches the predicted inventory, and the eMLR slightly overestimates the column inventory. In the Southern Ocean, the eMLR reproduces the predicted inventory, whereas the $\Delta C^{*}$ estimate displays significant deviations from the predicted inventory. Finally, in the North Atlantic the $\Delta C^{*}$ technique overestimates the anthropogenic inventory, and the eMLR underestimates the anthropogenic inventory. Our previous analysis showed that $\Delta C^{*}$ significantly underestimates $\Delta C_{\text {anthro }}$ concentrations in the upper $500 \mathrm{~m}$ between $40^{\circ} \mathrm{N}$ and $60^{\circ} \mathrm{N}$ relative to the predicted signal (Figure 4b). However, the column inventory for this region shows that $\Delta C^{*}$ overestimates the $\Delta C_{\text {anthro inventory }}$ (Figure 7). Similarly, the model transect analysis showed that the eMLR approach reproduces the predicted signal in the North Atlantic (Figure 4d), whereas the inventory analysis indicates that the eMLR significantly underestimates $\Delta C_{\text {anthro }}$ in this region (Figure 7). The discrepancies between the depth distribution of $\Delta C_{\text {anthro }}$ along the model transect and the column inventories for the model transect highlight the fact that small errors in these methods can result in significant discrepancies in inventory calculations when integrated over large depth ranges.

\section{Global Analysis}

[37] As a final check of the $\Delta C^{*}$ and MLR techniques we analyze their ability to estimate both spatial patterns in water column inventory and the global inventory of anthropogenic carbon in the oceans by applying them to the global output of the CSM1.4 model. The natural variability of the global carbon system is estimated by calculating the RMS variability of the DIC column inventories for control run model years 101 to 450 using detrended annual mean model output. The highest variability occurs in the mode and deep water formation regions: the North Atlantic, the northwest Atlantic, and the northwest Pacific oceans (Figure 8a). The boundary between the Southern Ocean and the Indo-Pacific oceans is also a region of increased variability. Similar to the transect analysis, we test the ability of the $\Delta C^{*}$ and MLR techniques to remove the natural variability in the model ocean carbon system by calculating $\Delta C_{\text {anthro, }}^{C^{*}}$, $\Delta C_{\text {anthro }}^{\mathrm{MLR}}$, and $\Delta C_{\text {anthro }}^{\mathrm{eMLR}}$ for the control run using detrended annual mean model output for model years 101 to 450 . The MLR calculations are done by basin (Atlantic, Pacific, Southern Ocean, Indian, and Arctic) as different water masses display different regional relationships between temperature, salinity, and nutrients. This basin approach reduces the RMS $1 \sigma$ difference between $\Delta C_{\text {anthro }}^{\text {predicted }}$ and $\Delta C_{\text {anthro }}^{\mathrm{MLR}}$ column inventories by $16.73 \mathrm{~mol} \mathrm{~m}^{-2}$ compared to the RMS difference for a single-MLR fit. All MLR fits are done for 200-2000 m, and baseline MLR parameters $p\left(t_{0}\right)$ (equation (8)) are computed using the mean DIC, nutrient, and physical fields. The results are similar to those of the model transect analysis. The $\Delta C^{*}$ method is able to remove the majority of the natural variability in the ocean carbon system but fails to account for some variability in the mode and deep water formation regions, particularly in the North 
a) DIC 1ofor CSM1.4

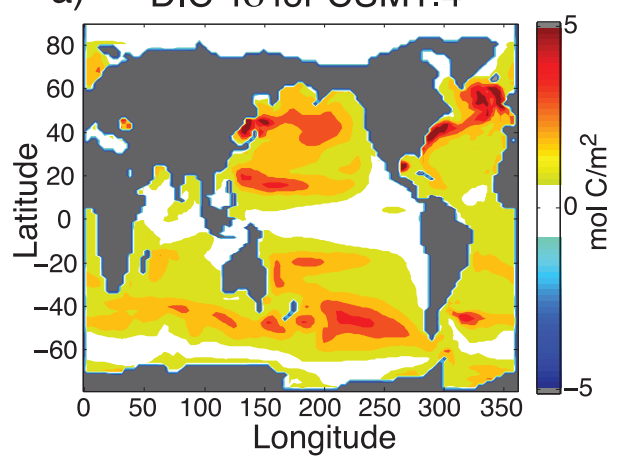

c) MLR 1ofor CSM1.4

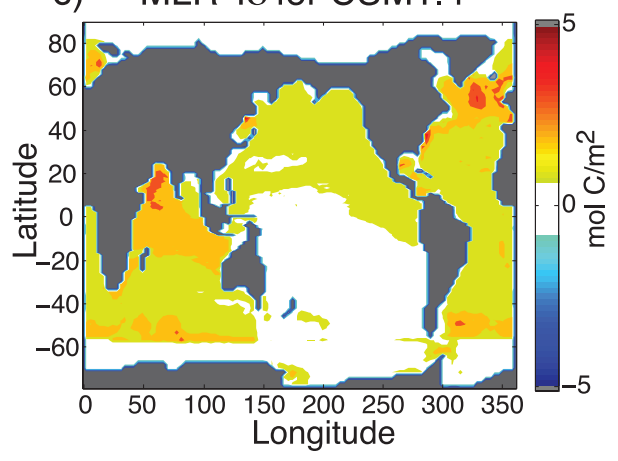

b) $\Delta C^{*}$ 1ofor CSM1.4
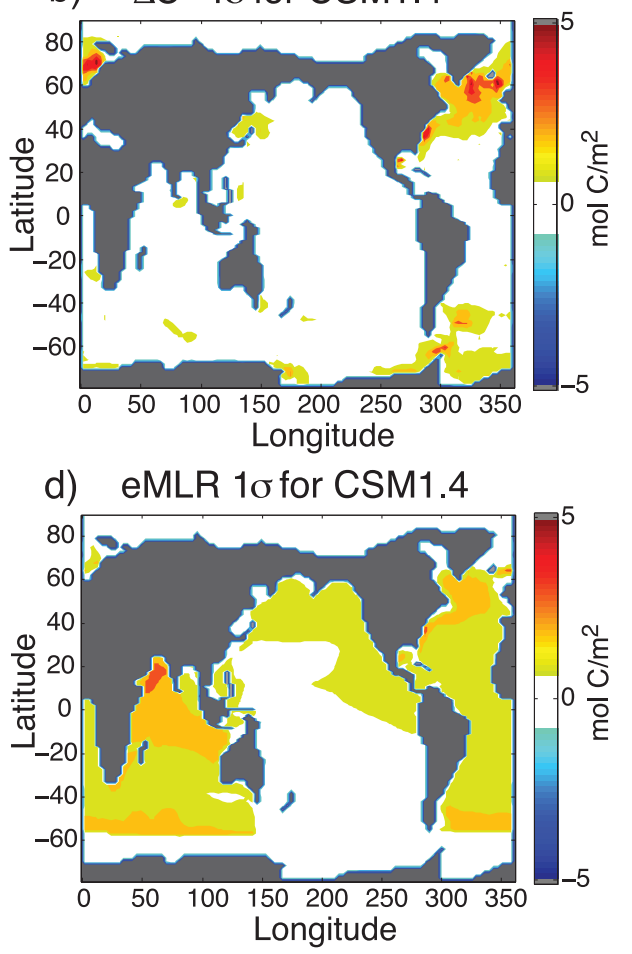

Figure 8. Spatial maps of CSM1.4 model output showing DIC column inventory (200-2000 m) RMS variability $(1 \sigma)$ for (a) model DIC output, (b) $\Delta C^{*}$, (c) MLR, and (d) eMLR calculated using years 101450 of the 1000 year control run.

Atlantic (Figure 8b). The MLR approaches also reduce the natural DIC variability but fail to account for some of the variability in the North Atlantic, South Atlantic, and North Indian oceans (Figures $8 \mathrm{c}$ and $8 \mathrm{~d}$ ). These areas, where the empirical methods are unable to remove all the variability in the natural carbon system, indicate regions where these empirical methods might not produce an accurate estimate of $\Delta C_{\text {anthro. }}$.

[38] Using a low-pass filter applied to the annual mean model output for each model cell, we estimate the predicted anthropogenic signal for the global output of the transient run, 2000-2100, and calculate the change in the column inventories for the decade with an average atmospheric $\mathrm{CO}_{2}$ of $375 \mathrm{ppm}$. The predicted estimate of the global accumulation of anthropogenic carbon is $23.2 \mathrm{Pg} \mathrm{C}$ per decade or $12.1 \mathrm{Pg} \mathrm{C}$ per decade for $200-2000 \mathrm{~m}$. The spatial distribution of the predicted accumulation for 200 $2000 \mathrm{~m}$ is shown in Figure 9a. The difference between the column inventories of the model DIC output for the decade under study yields a similar column inventory of $22.7 \mathrm{Pg}$ C per decade or $11.7 \mathrm{Pg} \mathrm{C}$ per decade for $200-2000 \mathrm{~m}$. However, there are significant discrepancies between the predicted distribution of anthropogenic $\mathrm{CO}_{2}$ and the "snapshot" difference in DIC. Applying the $\Delta C^{*}$, MLR, and eMLR techniques to the global model output yields global inventory estimates for $200-2000 \mathrm{~m}$ of $14.3,14.8$, and 13.6 Pg C per decade, respectively. The differences between $\Delta C_{\text {anthro }}^{\text {predicted }}$ and $\Delta C_{\text {anthro }}^{C^{*}} \Delta C_{\text {anthro, }}^{\mathrm{MLR}}$, and $\Delta C_{\text {anthro }}^{\mathrm{eMLR}}$ are shown in Figures $9 \mathrm{~b}, 9 \mathrm{c}$, and $9 \mathrm{~d}$, respectively. Both methods capture the basic trends of the predicted signal but tend to overestimate $\Delta C_{\text {anthro }}$ in some regions and underestimate $\Delta C_{\text {anthro }}$ in others. For example, the $\Delta C^{*}$ method overestimates $\Delta C_{\text {anthro }}$ in the North Atlantic and South Pacific and slightly underestimates $\Delta C_{\text {anthro }}$ in regions of the Southern Ocean. On the other hand, the eMLR underestimates $\Delta C_{\text {anthro }}$ in the North Atlantic and overestimates $\Delta C_{\text {anthro }}$ in the South Atlantic. The MLR shows the largest deviations from the predicted values (note the scale difference in Figure 9c) with large overestimates in the North Atlantic and North Indian Ocean and large underestimates in the tropical Atlantic, in the southwest Pacific, and along the Southern Ocean boundary.

\section{Discussion and Summary}

[39] Using the output of a coupled carbon-climate model, we evaluate the ability of empirical techniques to accurately estimate the uptake of anthropogenic carbon, $\Delta C_{\text {anthro, }}$ on decadal timescales in the presence of natural variability. This analysis shows that the $\Delta C^{*}$ and the extended MLR techniques have similar average errors for decadal differences (24\% and 26\%, respectively) and similar RMS errors (but somewhat different error sources and patterns), and both reproduce the spatial and temporal trends of the predicted anthropogenic signal for the majority of the ocean. However, this study also identifies regions where the empirical estimates of $\Delta C_{\text {anthro }}$ may introduce errors. Specifically, the $\Delta C^{*}$ estimates of $\Delta C_{\text {anthro }}$ may contain errors at high 

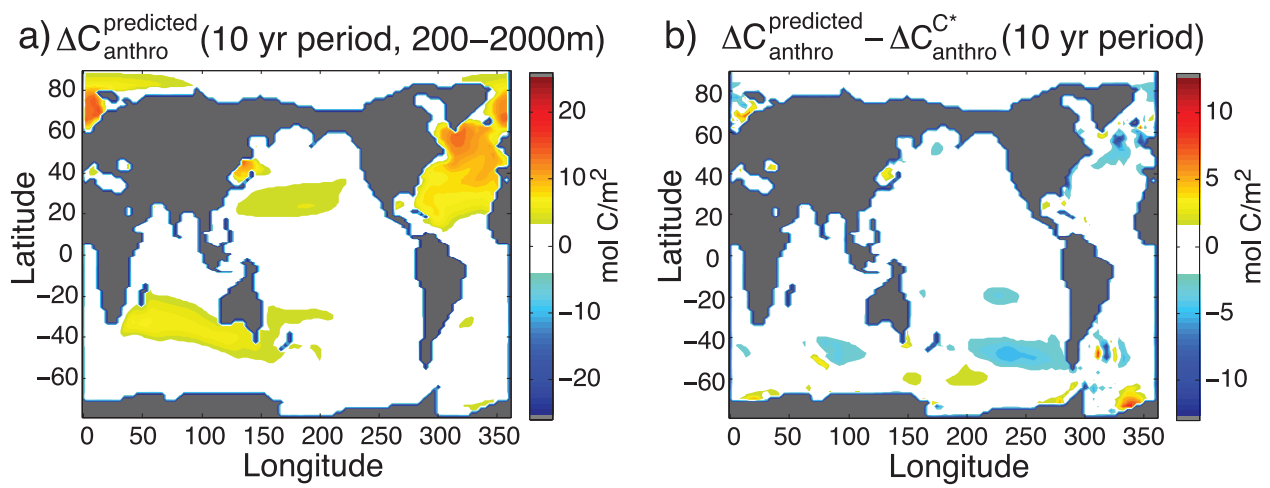

c) $\Delta \mathrm{C}_{\text {anthro }}^{\text {predicted }}-\Delta \mathrm{C}_{\text {anthro }}^{\mathrm{MLR}}(10 \mathrm{yr}$ period $)$
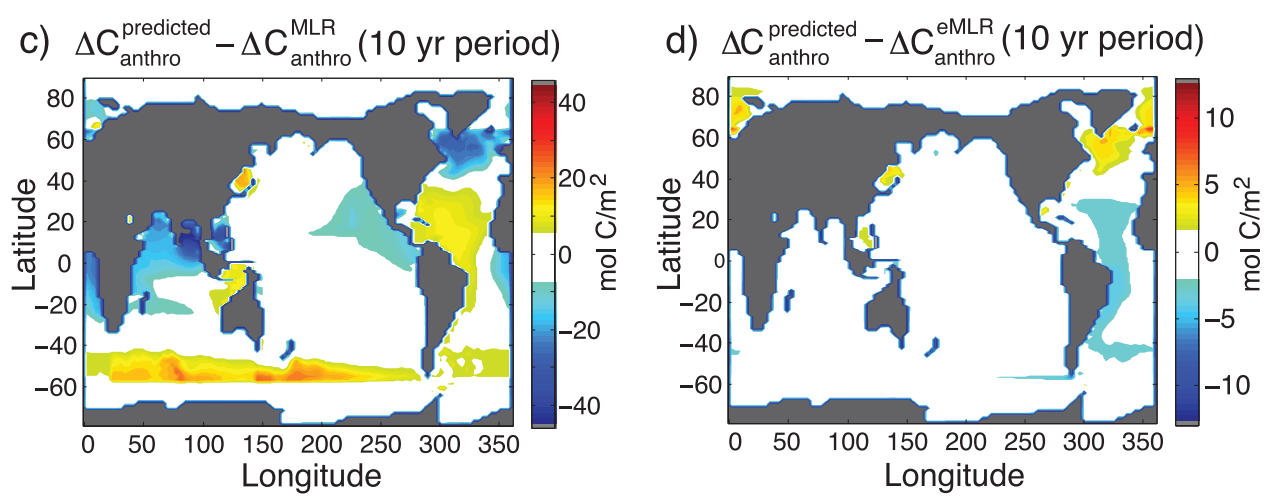

Figure 9. Spatial maps of CSM1.4 model output showing column inventories (200-2000 m) in mol $\mathrm{m}^{-2}$ of (a) $\Delta C_{\text {anthrod }}^{\text {predict }}$ (b) the difference between $\Delta C_{\text {anthro }}^{\text {prediced }}$ and $\Delta C_{\text {anthro, }}^{C^{*}}$ (c) the difference between $\Delta C_{\text {anthro }}^{\text {predicted }}$ and $\Delta C_{\text {anthro }}^{\mathrm{MLR}}$, and (d) the difference between $\Delta C_{\text {anthro }}^{\text {predicted }}$ and $\Delta C_{\text {anthro }}^{\text {eMLr }}$ for a 10 year period with an average atmospheric $\mathrm{CO}_{2}$ of $375 \mathrm{ppm}$. Note the difference in scale for Figures 6a and 6c. 
a)

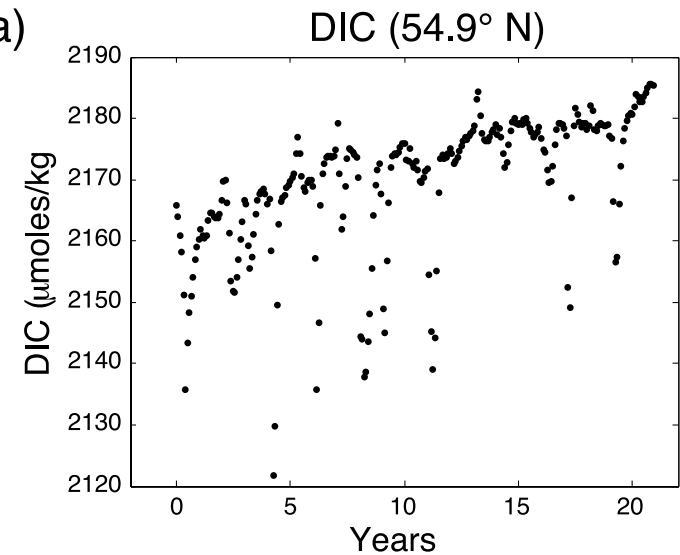

c)

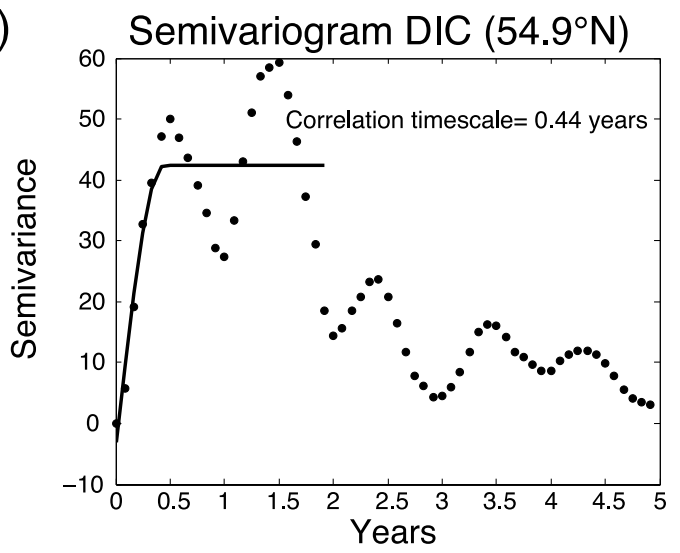

b) Fraction of Total Variance $\left(54.9^{\circ} \mathrm{N}\right)$

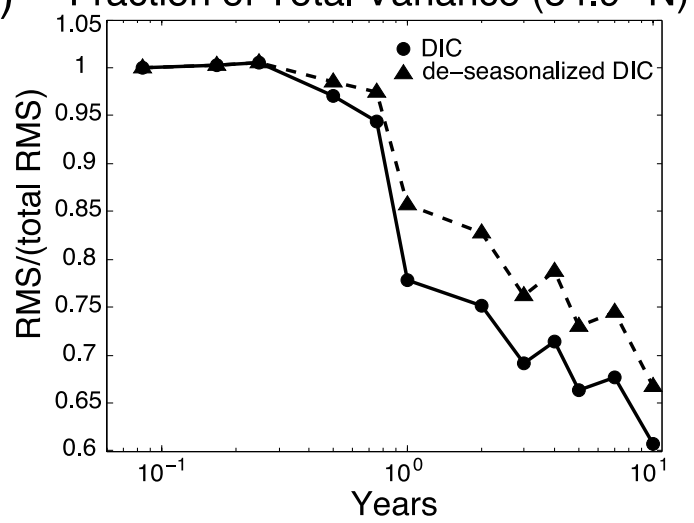

d)

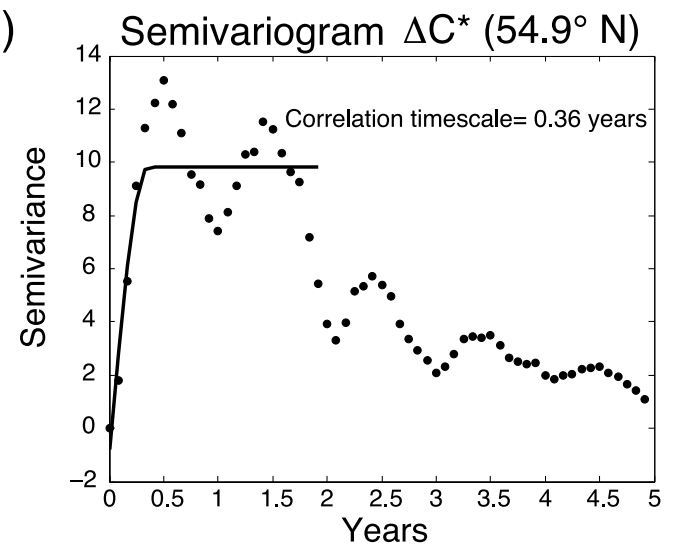

Figure 10. Correlation timescales for CSM1.4 model output along the A16 transect at $245 \mathrm{~m}$ and $54.9^{\circ} \mathrm{N}$ showing (a) raw DIC data for a 20 year period with an average atmospheric $\mathrm{CO}_{2}$ of $375 \mathrm{ppm}$ and $(\mathrm{b}-\mathrm{d})$ the timescales on which data in this region become decorrelated. The fraction of total variance (Figure 10b) compares the variability for a 10 year period captured by subsampling on timescales ranging from 2 months to 10 years to the total variability. The significant decrease in RMS/(total RMS) between 9 months and 1 year indicates that subannual sampling is necessary to capture the full variability in the system. The semivariance and best fit semivariogram of deseasonalized, detrended DIC data (Figure 10c) and $\Delta C^{*}$ data (Figure 10d) are also shown. The correlation timescales indicate the range over which samples are correlated ( 0.44 and 0.36 years, respectively).

latitudes, particularly in mode and deep water formation regions, because of variations in $\mathrm{O}_{2}$ and DIC air-sea disequilibrium. The MLR techniques are biased by structure in the MLR residuals, resulting from coherence between the MLR variables. Similar to the $\Delta C^{*}$ method, this is particularly apparent in mode and deep water formation regions where the residuals show significant degrees of structure. In addition, both empirical methods have difficulty in the upper $200 \mathrm{~m}$ because of high seasonal variability. Because of these potentially substantial errors in the empirical estimates of $\Delta C_{\text {anthro, }}$, we suggest that multiple empirical techniques should be used to estimate increases of anthropogenic carbon in the ocean. Specifically, careful attention should be paid to regions with significant differences between empirical estimates as this indicates that neither estimate is particularly robust and that further investigation is needed to fully characterize the underlying natural variability of the system.

[40] The results of this study also have significant implications for repeat hydrography programs, such as CLIVAR/ $\mathrm{CO}_{2}$. While decadal occupations might be sufficient to estimate the temporal change in $C_{\text {anthro }}$ for some regions of the ocean, this study suggests that there are regions where more frequent observations may be needed in order to better constrain the natural variability of the carbon system and therefore the anthropogenic signal, for example, in mode, intermediate, and deep water formation regions, such as in the subpolar North Atlantic. With increased temporal resolution, short-term natural variability in the ocean carbon system can be separated from the longer-term anthropogenic trend using approaches similar to the spline-fitting method presented in section 2 or by using the detailed record to more accurately attribute changes in DIC to biological and physical processes.

[41] A semivariogram analysis indicates that highly variable regions, such as the subpolar North Atlantic, have very short correlation timescales, on the order of half a year (Figure 10), indicating that subannual sampling is necessary to capture the full variability of the system. This is confirmed by an analysis of the fraction of the total variance captured under a variety of sampling scenarios ranging from every 2 months to every 10 years. In regions with low variability (e.g., $29^{\circ} \mathrm{S}, 415 \mathrm{~m}$ ), subsampling once every 
2 years captures nearly all of the variability in the system (not shown). However, in regions of high variability (e.g., $55^{\circ} \mathrm{N}, 245 \mathrm{~m}$ ), subsampling once a year captures only $78 \%$ of the total variability when raw data is analyzed and $86 \%$ of the total variability when deseasonalized data is analyzed (Figure 10). As such subannual sampling is impractical using traditional ship-based methods, we recommend that reoccupations be augmented where possible with alternative sampling platforms (e.g., moorings and profiling floats) and coherence with other biogeochemical variables such as $\mathrm{O}_{2}$ and nutrients.

[42] Acknowledgments. We would like to acknowledge funding from NSF (OCE02-23869), NCAR, the WHOI Ocean Climate Institute, a Linden Earth Systems Graduate Fellowship (MIT), and a National Defense Science and Engineering Graduate Fellowship. NCAR is sponsored by the National Science Foundation. R.W. is supported by the Office of Oceanic and Atmospheric Research at NOAA. We would also like to acknowledge the helpful comments of anonymous reviewers.

\section{References}

Anderson, L. A., and J. L. Sarmiento (1994), Redfield ratios of remineralization determined by nutrient data-analysis, Global Biogeochem. Cycles, 8(1), 65-80.

Blackmon, M., et al. (2001), The community climate system model, Bull. Am. Meteorol. Soc., 82, 2357-2376.

Brewer, P. G. (1978), Direct observation of oceanic $\mathrm{CO}_{2}$ increase, Geophys. Res. Lett., 5, 997-1000.

Brewer, P. G., D. M. Glover, C. Goyet, and D. K. Shafer (1995), The pH of the North Atlantic Ocean: Improvements to the global model for sound absorption in seawater, J. Geophys. Res., 100(C5), 8761-8776.

Chen, G. T., and F. J. Millero (1979), Gradual increase of oceanic $\mathrm{CO}_{2}$, Nature, 277, 205-206.

Coatanoan, C., C. Goyet, N. Gruber, C. L. Sabine, and M. Warner (2001), Comparison of two approaches to quantify anthropogenic $\mathrm{CO}_{2}$ in the ocean: Results from the northern Indian Ocean, Global Biogeochem. Cycles, 15(1), 11-25.

Dilling, L., S. C. Doney, J. Edmonds, K. R. Gurney, R. Harriss, D. Schimel, B. Stephens, and G. Stokes (2003), The role of carbon cycle observations and knowledge in carbon management, Annu. Rev. Environ. Res., 28, $521-558$.

Doney, S. C., K. Lindsay, I. Fung, and J. John (2006), Natural variability in a stable, 1000-yr global coupled climate-carbon cycle simulation, J. Clim., 19, 3033-3054.

Etheridge, D. M., L. P. Steele, R. L. Langenfelds, R. J. Francey, J.-M. Barnola, and V. I. Morgan (1996), Natural and anthropogenic changes in atmospheric $\mathrm{CO}_{2}$ over the last 1000 years from air in Antarctic ice and firn, J. Geophys. Res., 101(D2), 4115-4128.

Feely, R. A., R. Wanninkhof, T. Takahashi, and P. Tans (1999), Influence of El Nino on the equatorial Pacific contribution to atmospheric $\mathrm{CO}_{2}$ accumulation, Nature, 398, 597-601.

Friedlingstein, P., et al. (2006), Climate-carbon cycle feedback analysis: Results from the $\mathrm{C}^{4} \mathrm{MIP}$ model intercomparison, J. Clim., 19, $3337-$ 3353.

Friis, K., A. Kortzinger, J. Patsch, and D. W. R. Wallace (2005), On the temporal increase of anthropogenic $\mathrm{CO}_{2}$ in the subpolar North Atlantic, Deep Sea Res., Part I, 52, 681-698.

Fung, I. Y., S. C. Doney, K. Lindsay, and J. John (2005), Evolution of carbon sinks in a changing climate, Proc. Natl. Acad. Sci. U.S.A., 102, $11,201-11,206$.

Gent, P. R., F. O. Bryan, G. Danabasoglu, S. C. Doney, W. R. Holland, W. G. Large, and J. C. McWilliams (1998), The NCAR climate system model global ocean component, J. Clim., 11, 1287-1306.

Goyet, C., and D. Davis (1997), Estimation of total $\mathrm{CO}_{2}$ concentration throughout the water column, Deep Sea Res., Part I, 44, 859-877.

Goyet, C., C. Coatanoan, G. Eischeid, T. Amaoka, K. Okuda, R. Healy, and S. Tsunogai (1999), Spatial variation of total $\mathrm{CO}_{2}$ and total alkalinity in the northern Indian Ocean: A novel approach for the quantification of anthropogenic $\mathrm{CO}_{2}$ in seawater, J. Mar. Res., 57, 135-163.

Gruber, N. (1998), Anthropogenic $\mathrm{CO}_{2}$ in the Atlantic Ocean, Global Biogeochem. Cycles, 12(1), 165-191.

Gruber, N., and J. Sarmiento (2002), Biologeochemical/physical interactions in elemental cycles, in The Sea: Biological-Physical Interactions in the Oceans, edited by A. R. Robinson et al., pp. 337-399, John Wiley, Hoboken, N. J.
Gruber, N., J. L. Sarmiento, and T. F. Stocker (1996), An improved method for detecting anthropogenic $\mathrm{CO}_{2}$ in the oceans, Global Biogeochem. Cycles, 10(4), 809-837.

Haine, T. W. N., and S. L. Gray (2001), Quantifying mesoscale variability in ocean transient tracer fields, J. Geophys. Res., 106(C7), 13,86113,878 .

Hansen, J., M. Sato, R. Ruedy, K. Lo, D. W. Lea, and M. Medina-Elizade (2006), Global temperature change, Proc. Natl. Acad. Sci. U.S.A., 103, $14,288-14,293$.

Intergovernmental Panel on Climate Change (IPCC) (2000), Special Report on Emission Scenarios, edited by N. Nakicenovic et al., 612 pp., Cambridge Univ. Press, New York.

Intergovernmental Panel on Climate Change (IPCC) (2001), Climate Change 2001: The Scientific Basis: Contribution of Working Group I to the Third Assessment Report of the Intergovernmental Panel on Climate Change, edited by J. T. Houghton et al., 881 pp., Cambridge Univ. Press, New York.

Johnson, G. C., and N. Gruber (2007), Decadal water mass variations along 20 degrees $\mathrm{W}$ in the Northeastern Atlantic Ocean, Prog. Oceanogr., 73, $277-295$.

Johnson, G. C., J. L. Bullister, and N. Gruber (2005), Labrador Sea water property variations in the northeastern Atlantic Ocean, Geophys. Res. Lett., 32, L07602, doi:10.1029/2005GL022404.

Keeling, C. D., and T. P. Whorf (1994), Atmospheric $\mathrm{CO}_{2}$ records from sites in the SIO air sampling network, in Trends '93: A Compendium of Data on Global Change, ORNL/CDIAC-65, pp. 16-26, edited by T. A. Boden et al., Carbon Dioxide Inf. Anal. Cent., Oak Ridge Natl. Lab., Oak Ridge, Tenn.

Keeling, C. D., R. B. Bacastow, A. E. Bainbridge, C. A. Ekdahl, P. R. Guenther, and L. S. Waterman (1976), Atmospheric carbon-dioxide variations at Mauna-Loa Observatory, Hawaii, Tellus, 28, 538-551.

Lee, K., et al. (2003), An updated anthropogenic $\mathrm{CO}_{2}$ inventory in the Atlantic ocean, Global Biogeochem. Cycles, 17(4), 1116, doi:10.1029/ 2003 GB002067.

Le Quere, C., O. Aumont, P. Monfray, and J. Orr (2003), Propagation of climatic events on ocean stratification, marine biology, and $\mathrm{CO}_{2}$ : Case studies over the 1979-1999 period, J. Geophys. Res., 108(C12), 3375, doi:10.1029/2001JC000920.

Lo Monaco, C., C. Goyet, N. Metzl, A. Poisson, and F. Touratier (2005), Distribution and inventory of anthropogenic $\mathrm{CO}_{2}$ in the Southern Ocean: Comparison of three data-based methods, J. Geophys. Res., 110, C09S02, doi:10.1029/2004JC002571.

Lovenduski, N. S., N. Gruber, S. C. Doney, and I. D. Lima (2007), Enhanced $\mathrm{CO}_{2}$ outgassing in the Southern Ocean from a positive phase of the Southern Annular Mode, Global Biogeochem. Cycles, 21, GB2026, doi:10.1029/2006GB002900.

Martin, J. H., G. A. Knauer, D. M. Karl, and W. W. Broenkow (1987), Vertex - carbon cycling in the northeast Pacific, Deep Sea Res., Part A, $34,267-285$.

Matsumoto, K., and N. Gruber (2005), How accurate is the estimation of anthropogenic carbon in the ocean? An evaluation of the $\Delta C^{*}$ method, Global Biogeochem. Cycles, 19, GB3014, doi:10.1029/2004GB002397.

McNeil, B. I., R. J. Matear, R. M. Key, J. L. Bullister, and J. L. Sarmiento (2003), Anthropogenic $\mathrm{CO}_{2}$ uptake by the ocean based on the global chlorofluorocarbon data set, Science, 299, 235-239.

Moore, J. K., S. C. Doney, and K. Lindsay (2004), Upper ocean ecosystem dynamics and iron cycling in a global three-dimensional model, Global Biogeochem. Cycles, 18, GB4028, doi:10.1029/2004GB002220.

Najjar, R., and J. Orr (1999), Biotic-HOWTO, 15 pp., Lab. des Sci. du Climat et de l'Environnement/Comm. à l'Energ. At. Saclay, Gif-surYvette, Paris.

Najjar, R., et al. (2007), Impact of circulation on export production, dissolved organic matter, and dissolved oxygen in the ocean: Results from Phase II of the Ocean Carbon-cycle Model Intercomparison Project (OCMIP-2), Global Biogeochem. Cycles, 21, GB3007, doi:10.1029/ 2006 GB002857.

Peacock, S., M. Maltrud, and R. Bleck (2005), Putting models to the data test: A case study using Indian Ocean CFC-11 data, Ocean Modell., 9, $1-22$.

Peltola, E., et al. (2005), , Inorganic carbon, nutrient, and oxygen data from the R/V Ronald H. Brown Repeat Hydrography Cruise in the Atlantic Ocean: CLIVAR $\mathrm{CO}_{2}$ section A16N_2003A (4 June-11 August, 2003), ORNL RNL/CDIAC-149 NDP-085, 20 pp., Carbon Dioxide Inf. Anal. Cent., Oak Ridge Natl. Lab., Oak Ridge, Tenn. (Available at http://cdiac. ornl.gov/oceans/ndp_085/NDP-085.html)

Peng, T. H. (2005), Anthropogenic $\mathrm{CO}_{2}$ in the ocean, Sci. Mar., 69, 85-96.

Peng, T. H., R. Wanninkhof, J. L. Bullister, R. A. Feely, and T. Takahashi (1998), Quantification of decadal anthropogenic $\mathrm{CO}_{2}$ uptake in the ocean based on dissolved inorganic carbon measurements, Nature, 396, 560563 . 
Peng, T. H., R. Wanninkhof, and R. A. Feely (2003), Increase of anthropogenic $\mathrm{CO}_{2}$ in the Pacific Ocean over the last two decades, Deep Sea Res., Part II, 50, 3065-3082.

Quay, P., R. Sonnerup, T. Westby, J. Stutsman, and A. McNichol (2003), Changes in the ${ }^{13} \mathrm{C} /{ }^{12} \mathrm{C}$ of dissolved inorganic carbon in the ocean as a tracer of anthropogenic $\mathrm{CO}_{2}$ uptake, Global Biogeochem. Cycles, 17(1), 1004, doi:10.1029/2001GB001817.

Sabine, C. L., and R. A. Feely (2001), Comparison of recent Indian Ocean anthropogenic $\mathrm{CO}_{2}$ estimates with a historical approach, Global Biogeochem. Cycles, 15(1), 31-42.

Sabine, C. L., R. Key, K. Johnson, F. Millero, A. Poisson, J. Sarmiento, D. Wallace, and C. Winn (1999), Anthropogenic $\mathrm{CO}_{2}$ inventory of the Indian Ocean, Global Biogeochem. Cycles, 13(1), 179-198.

Sabine, C. L., R. A. Feely, R. M. Key, J. L. Bullister, F. J. Millero, K. Lee, T.-H. Peng, B. Tilbrook, T. Ono, and C. S. Wong (2002), Distribution of anthropogenic $\mathrm{CO}_{2}$ in the Pacific Ocean, Global Biogeochem. Cycles, 16(4), 1083, doi:10.1029/2001GB001639.

Sabine, C. L., et al. (2004a), The oceanic sink for anthropogenic $\mathrm{CO}_{2}$, Science, 305, 367-371.

Sabine, C. L., R. A. Feely, Y. W. Watanabe, and M. Lamb (2004b), Temporal evolution of the North Pacific $\mathrm{CO}_{2}$ uptake rate, J. Oceanogr., 60 , $5-15$.

Touratier, F., and C. Goyet (2004a), Applying the new TrOCA approach to assess the distribution of anthropogenic $\mathrm{CO}_{2}$ in the Atlantic Ocean, J. Mar. Syst., 46, 181-197.

Touratier, F., and C. Goyet (2004b), Definition, properties, and Atlantic Ocean distribution of the new tracer TrOCA, J. Mar. Syst., 46, 169-179.

Touratier, F., C. Goyet, C. Coatanoan, and C. Andrié (2005), Assessments of anthropogenic $\mathrm{CO}_{2}$ distribution in the tropical Atlantic Ocean, Deep Sea Res., Part I, 52, 2275-2284.

Wallace, D. (1995), Monitoring global ocean carbon inventories, 54 pp., Ocean Obs. Syst. Dev. Panel, Tex. A\&M Univ., College Station.

Wallace, D. (2001), Storage and transport of excess $\mathrm{CO}_{2}$ in the ocean: The JGOFS/WOCE global $\mathrm{CO}_{2}$ survey, in Ocean Circulation and Climate, edited by G. Siedler et al., pp. 489-521, Acedmic, San Diego, Calif.
Wanninkhof, R., S. C. Doney, T. H. Peng, J. L. Bullister, K. Lee, and R. A. Feely (1999), Comparison of methods to determine the anthropogenic $\mathrm{CO}_{2}$ invasion into the Atlantic Ocean, Tellus, Ser. B, 51, 511-530.

Wanninkhof, R., S. Doney, J. L. Bullister, N. Gruber, C. Sabine, R. A Feely, G. C. Johnson, and F. Millero (2006a), Changes in inorganic carbon inventory in the Atlantic Ocean over the last decade, EoS Trans. $A G U, 87(36)$, Ocean Sci. Meet. Suppl., Abstract OS52C-01.

Wanninkhof, R., et al. (2006b), Carbon Dioxide, Hydrographic, and Chemical Data Obtained During the R/V Ronald H. Brown Repeat Hydrography Cruise in the Atlantic Ocean: CLIVAR $\mathrm{CO}_{2}$ Section A16S 2005 (11 January-24 February, 2005), 38 pp., Carbon Dioxide Inf. Anal. Cent., Oak Ridge Natl. Lab., Oak Ridge, Tenn. (Available at http:// cdiac.ornl.gov/oceans/ndp 087/NDP-087.html)

Waugh, D. W., T. M. Hall, B. I. McNeil, R. Key, and R. J. Matear (2006), Anthropogenic $\mathrm{CO}_{2}$ in the oceans estimated using transit time distributions, Tellus, Ser. B, 58, 376-389.

Weiss, R. F. (1970), The solubility of nitrogen, oxygen, and argon in water and seawater, Deep Sea Res., 17, 721-735.

Zeebe, R. E., and D. A. Wolf-Gladrow (2001), $\mathrm{CO}_{2}$ in Seawater: Equilibrium, Kinetics, Isotopes, Elsevier Oceanogr. Ser., vol. 65, 346 pp., Elsevier, Amsterdam.

S. C. Doney, Marine Chemistry and Geochemistry Department, Woods Hole Oceanographic Institution, Woods Hole, MA 02543, USA.

I. Y. Fung, Berkeley Atmospheric Sciences Center, University of California, Berkeley, Berkeley, CA 94720-4767, USA. (sdoney@whoi.edu)

N. M. Levine, Massachusetts Institute of Technology/Woods Hole Oceanographic Institution Joint Program, Woods Hole, MA 02543, USA. (nlevine@whoi.edu)

K. Lindsay, Climate and Global Dynamics, National Center for Atmospheric Research, Boulder, CO 80307, USA.

R. Wanninkhof, Atlantic Oceanographic and Meteorological Laboratory, NOAA, Miami, FL 33149, USA. 